This document is the accepted manuscript version of the following article:

Meadows, P. J., Andresen, P. L., Toloczko, M. B., Kuang, W. J., Ritter, S., Bjurman, M., ... Mottershead, K. J. (2020).

International round-robin on stress corrosion crack initiation of Alloy 600 material in pressurized water reactor primary

water. Corrosion, 76(8), 719-733. https://doi.org/10.5006/3532

B. Stress corrosion

\section{International Round-Robin on Stress Corrosion Crack Initiation of Alloy 600 Material in Pressurized Water Reactor Primary Water}

\author{
P.J. Meadows*, P.L. Andresen**, M.B. Toloczko***, \\ W-J. Kuang****, S. Ritter*****, \\ M. Bjurman******, L. Zhang*******, \\ M. Ernestova********, A. Toivonen*********, \\ F. Perosanz-Lopez $* * * * * * * * * *$, J.W. Stairmand*, \\ K.J. Mottershead*
}

*Jacobs, Walton House, Faraday Street, Birchwood Park, Warrington, Cheshire, WA3 6GA, UK

**General Electric Global Research Center, Schenectady, $N Y$, USA
***Pacific Northwest National Laboratory, Richland, WA, USA

****University of Michigan, Ann Arbor, MI, USA

*****Paul Scherrer Institute (PSI), Villigen, Switzerland

******Studsvik Nuclear AB, Nykoping, Sweden

*******Shanghai Jiao-Tong University, Shanghai, China

********UJV Rez (a.s.), Czech Republic

*********VTT Technical Research Centre of Finland Ltd., Espoo, Finland

**********CIEMAT, Madrid, Spain

\section{ARTICLE INFO}

\section{Article history:}

Received Day Month Year

Accepted Day Month Year

Available Day Month Year

\section{Keywords:}

A. Nickel

A. Alloy

\begin{abstract}
The International Cooperative Group on Environmentally-Assisted Cracking of Water Reactor Materials coordinated an international "Round-Robin" collaboration of ten laboratories on stress corrosion crack (SCC) initiation in three heats of cold-worked Alloy 600 in hightemperature water.
\end{abstract}

The various laboratories were able to produce good quality experimental crack initiation data, and the Round-Robin exercise highlighted the benefits in generating a significant body of data when assessing the susceptibility of a material to SCC. The compilation of data from multiple laboratories using common test techniques greatly assists the understanding of the material variability and gives confidence in the reliability of the results.

\section{INTRODUCTION}

The International Cooperative Group on Environmentally-Assisted Cracking of Water Reactor Materials (ICG-EAC, N.P.O.) is a non-profit organization composed of international experts in environmentallyassisted cracking in high-temperature water that has met every year since 1978, with 86 member organizations from 18 countries. The organizing committee also periodically coordinates international efforts in areas of significant interest among its members.

In 2016 the ICG-EAC decided to coordinate an international RoundRobin on experimental measurements of initiation of stress corrosion cracking (SCC). The need for more sophisticated initiation testing has become more acute, and a major focus has been placed on active loading and in-situ monitoring by Direct Current Potential Drop (DCPD) to provide real-time measurements of cracking. These are removing much of the uncertainty inherent in more 'traditional' initiation testing, where specimens were bolt-loaded or formed into U-bends, and tests were periodically interrupted to estimate initiation times. Load relaxation, uncertainty in initiation time and crack evolution, and variability from laboratory-to-laboratory were concerns, with different test arrangements and laboratory practices. In the ICG-EAC RoundRobin, the participating laboratories were:

I. WOOD - Wood plc (nowadays: Jacobs), Birchwood, UK

II. GE-GRC - General Electric Global Research Center, Schenectady, NY, USA

III. PNNL - Pacific Northwest National Laboratory, Richland, WA, USA

IV. MICHIGAN - University of Michigan, Ann Arbor, MI, USA

V. PSI - Paul Scherrer Institute, Villigen, Switzerland

VI. STUDSVIK - Studsvik Nuclear AB, Nykoping, Sweden

VII. SJTU - Shanghai Jiao-Tong University, Shanghai, China

VIII. UJV - UJV Rez (a.s.), Czech Republic

IX. VTT - VTT Technical Research Centre of Finland Ltd., Espoo, Finland

X. CIEMAT - CIEMAT, Madrid, Spain

To achieve comparisons between laboratories within practical timescales, the materials being tested had to have significant susceptibility to SCC. For this reason, Alloy 600 (UNS N06600) material was chosen. To increase susceptibility, it was also decided that the Alloy 600 would be in the Mill Annealed (MA) or Solution Annealed (SA) condition, as these are known to be more susceptible to SCC than the Thermally Treated (TT) condition ${ }^{1-2}$. A moderate level of $15 \%$ cold 
work (thickness reduction by cold forging) was selected to promote SCC. There is a demonstrated dependency between time to initiation and strain (imparted in-test or by prior cold work); this was reported a number of years ago by Richey et al. ${ }^{3}$ There is also plant relevance to imparting strain in the test specimen as this can also be induced on components through fabrication and repair methods. While there has been a tendency to reduce the use of Alloy 600 in new-build light water reactors, a number of Alloy 600 components still remain in use, although few or none are in the SA or MA condition.

To generate data to evaluate lab-to-lab variability and data scatter, common test materials and test methodologies were required. To achieve this, a detailed test specification was produced, and three heats of Alloy 600 were made available for testing. This enabled heatto-heat variability to be investigated along with lab-to-lab variability. Each laboratory was required to perform initiation testing on the first common material (heat 1 ), with any data from the remaining heats welcomed by the Round-Robin committee if participants' testing capacity/programs allowed.

Ten laboratories from around the world have completed testing and reported results. Some of these laboratories were already established in the field of SCC initiation testing, and therefore included the RoundRobin tests into their ongoing test programs. Other laboratories were in a more developmental phase and were limited as to the conditions that could be achieved. For this reason, there were some differences in specimen designs and test conditions that deviated from those defined in the IGC-EAC specification document. When different methods, specimen types, or test temperatures were used, their effect could also be assessed from the collated dataset.

\section{TEST SPECIFICATION}

A detailed test specification was produced by the Round-Robin organizing committee, combining the established best practice in initiation testing with a choice of test conditions that would enable wide participation. Participants were encouraged to follow the specification as closely as possible to ensure consistency of the testing approach and facilitate comparison of results.

\section{Materials and specimen preparation}

Three heats of Alloy 600 material, in the mill annealed or solution annealed condition, were selected for the Round Robin tests: heat 1 (heat NX6106XK-11) - Supplied by PNNL4, heat 2 (heat 31907) Supplied by GE-GRC/EPRI and heat 3 (heat 11415) - Supplied by RollsRoyce. Test blocks were extracted from each of the materials, heat treated (heats 2 and 3 ), and then cold forged by $15 \%$ thickness reduction in a single press at room temperature by GE-GRC to ensure consistency of cold work of the blocks provided to participants.

Two specimen designs were specified, Figure 1; a button-ended specimen and a specimen with a reduced gauge section and a low strain region for reference probes. Specimens were extracted from the blocks with their lengths orientated in the cold forging direction to prevent orientation being a variable. This is also the most susceptible orientation for crack growth, although how orientation affects initiation time has not yet been established. Machining specifications were provided, along with a surface finish detailing a final polish using a fine grit paper or $1 \mu \mathrm{m}$ diamond paste.

\section{Test conditions}

The preferred test temperature was $350{ }^{\circ} \mathrm{C}$. If this was not achievable, an alternative test temperature of $320^{\circ} \mathrm{C}$ was proposed. However, some test program sponsors preferred tests to be performed at $360^{\circ} \mathrm{C}$ due to this temperature matching their programmatic needs.

To simulate pressurized water reactor (PWR) primary water conditions, the water composition was specified as:

- $2 \mathrm{ppm}$ lithium (as $\mathrm{LiOH}$ ) at a room temperature $\mathrm{pH}$ of 10.0 10.5.

- Boric acid added as 1000 ppm boron.

- $\quad$ Concentration of anionic species as low as reasonably practicable, and preferably $<20 \mathrm{ppb} \mathrm{Cl}^{-}$and $\mathrm{SO}_{4}{ }^{2-}$.

- Target electrochemical potential at the $\mathrm{Ni} / \mathrm{NiO}$ transition (with a preference to being at a slightly higher Electro Chemical Potential (ECP) but by no more than $5 \mathrm{mV}$ ). At $350{ }^{\circ} \mathrm{C}$, the $\mathrm{Ni} / \mathrm{NiO}$ phase boundary corresponds to a dissolved hydrogen concentration of $19.7 \mathrm{cc} \mathrm{H}_{2} / \mathrm{kg} \mathrm{H} 2 \mathrm{O}$ at STP, and at 320 and $360^{\circ} \mathrm{C}$, it is 9.15 and $25.4 \mathrm{cc} / \mathrm{kg}$, respectively.

\section{Specimen loading}

The load applied to the specimen(s) aimed to achieve a gauge section stress somewhat above the $0.2 \%$ yield stress at the chosen test temperature for the cold worked material supplied, with a preferred value of $1 \%$ above the yield stress. It was specified that the load should be increased from the low/no load condition to the target load by gradually applying the load over a period of not less than 2 hours. Any effects of pressure loading on the specimen and pull rod seal friction had to be accounted for when calculating the applied load.

\section{Monitoring of test specimens}

DCPD with resistivity correction was used to measure initiation and the early stages of crack growth. The resistivity of Alloy 600 increases as a function of time (in argon or water) in the temperature range of $\sim 280$ to $400{ }^{\circ} \mathrm{C}$, with a faster approach to an equilibrium resistivity occurring at higher temperature and in cold worked materials. This increase in resistivity can potentially delay the identification of initiation.

Use of a reference electrode and/or a Pt electrode was recommended for electrochemical potential monitoring. Initiation for these tests was defined as the time when an inflection in the reference-corrected DCPD response was observed, Figure 2 . This can be termed "practical SCC initiation" and may be the point at which short cracks develop and/or coalesce to form an SCC crack with sustained propagation. Prior to this point SCC tests have observed cracking phenomena such as very small cracks, intergranular attack or grain boundary oxidation. In some of these cases, sustained SCC propagation does not immediately follow these precursor events.

\section{MATERIALS CHARACTERIZATION}

Three materials (termed heat 1, 2 and 3) were available for testing with the Round-Robin. The compositions are detailed in Table 1. Material provenance is discussed below, and the elemental compositions for the major constituents $(\mathrm{Ni}, \mathrm{Fe}, \mathrm{Cr}$ ) are similar. There are compositional differences of the minor constituents, which may influence SCC susceptibility. Heat 3 (RR-A600) has a very low boron content. Heat 2 (31907) has very low carbon and sulfur contents.

\section{Heat 1 (NX6106XK-11)}

Alloy 600, heat NX6106XK-11, was supplied by PNNL, who purchased it as a $50 \mathrm{~mm}$ thick plate produced by Special Metals. The material was mill annealed at $1700^{\circ} \mathrm{F}\left(927^{\circ} \mathrm{C}\right)$ for 3.5 hours and water quenched (WQ). Blocks were cut from the plate and cold forged at room 
temperature to $15 \%$ thickness reduction using a single press by GEGRC. Cold forging was orientated in the same plane as the processing and banding planes (forging reduced the plate thickness). Tensile data were measured by four laboratories in air at temperatures from 320 $360{ }^{\circ} \mathrm{C}$, and the $0.2 \%$ proof stress ranged from $519-550 \mathrm{MPa}$. A hardness profile through one of the cold forged blocks confirmed reasonable uniformity, with an average hardness of 254 HV2O.

Microstructural characterization measured an average grain size of 65 $\mu \mathrm{m}$, with transgranular (TG) carbides on ghost grain boundaries and a non-uniform distribution of intergranular (IG) carbides. Bands of larger and smaller grains along the processing direction were also present. Some of the large "balloon" grains were highly elongated, exceeding $1 \mathrm{~mm}$ in length (Figure 3 ). This may have contributed to the variability in the initiation times observed for this heat.

\section{Heat 2 (31907)}

A second heat of Alloy 600 (31907) was provided by GE-GRC/EPRI, who purchased it from Foroni as a 6 inch diameter bar. The processing was defined in discussion between Foroni and GE-GRC, with a final mill annealed condition, $1742{ }^{\circ} \mathrm{F}\left(950^{\circ} \mathrm{C}\right)$ for 3 hours, then water quenched. The material was subsequently solution annealed at $1100^{\circ} \mathrm{C}$ for 30 minutes and water quenched by GE. The material was then cold forged at room temperature to $15 \%$ thickness reduction in a single press. The tensile properties were measured and the $0.2 \%$ proof stress reported to be $364 \mathrm{MPa}$ at $350^{\circ} \mathrm{C}$ and $372 \mathrm{MPa}$ at $330^{\circ} \mathrm{C}$. The hardness profile data for this material showed reasonable uniformity in the direction of forging, with an average hardness of 215 HV20. Microstructural examination of this material by SEM showed a duplex grain size distribution consisting of 50-200 $\mu \mathrm{m}$ grains and larger grains of $400-$ $600 \mu \mathrm{m}$ diameter (Figure 3). High resolution SEM imaging of grain boundaries revealed no evidence of IG precipitates. ${ }^{5}$

\section{Heat 3 (11415)}

The third heat of Alloy 600 was extracted from a development EAF-ESR ring forging produced by Rolls-Royce (heat 11415). This had been annealed at $950{ }^{\circ} \mathrm{C}$ for $3-4$ hours, air cooled and then thermally treated at $705^{\circ} \mathrm{C}$ for 15 hours. For the Round-Robin exercise the test blocks were solution annealed at $1050^{\circ} \mathrm{C}$ for 60 minutes, water-quenched and then cold forged at room temperature to $15 \%$ thickness reduction in a single press. The tensile properties of the material in this condition were measured for multiple specimens with the average $0.2 \%$ proof stress determined as $366 \mathrm{MPa}$ at $350{ }^{\circ} \mathrm{C}$ and $396 \mathrm{MPa}$ at $330{ }^{\circ} \mathrm{C}$. The hardness profile had reasonable uniformity in the cold forging direction and gave an average hardness of 206 HV20. Microstructural examination by optical microscopy, SEM, and EBSD showed the microstructure to be inhomogeneous (duplex), with regions of large grains, up to $500 \mu \mathrm{m}$ and other regions with smaller grains, $50-100$ $\mu \mathrm{m}$, Figure 3. High magnification SEM showed that no carbides were present on the grain boundaries following the solution anneal. ${ }^{5} \mathrm{~A}$ region of greater homogeneity was chosen for the forging of the round robin material.

A comparison of the microstructures imaged by EBSD are shown in Figure 4. A comparison of the stress-strain responses for the three heats, measured at $350^{\circ} \mathrm{C}$ in air, is shown in Figure 5.

\section{RESULTS}

Data was provided by the Round-Robin participants in the form of a summary spreadsheet, which presented the key information for each test. The participants were responsible for determining the initiation time from the inflection point in the DCPD data. All SCC initiation was confirmed by the respective participants by post-test specimen characterization which involved inspecting for SCC cracks, either by optical methods or by scanning electron microscopy.

\section{Heat 1 results}

Heat 1 material (NX6106XK-11) SCC initiation times were reported by nine laboratories. These were recorded at a range of test temperatures from $320-360^{\circ} \mathrm{C}$ and are detailed in Table 2 and Figure 6 (uncorrected for temperature). 'Run-outs' are shown by arrows for tests where time constraints were reached for test durations, or where failures in a multiple specimen chain meant that tests were not restarted. For unmonitored specimens, where cracking was identified by post-test characterization, the initiation time is less certain, and occurred at some time before the initiation time reported. These points are shown by downward arrows which indicate that the actual initiation time was shorter. The DCPD response for this material was distinct, with initiation times easily discerned to \pm 20 hours. The dominant crack propagated quickly after initial detection, in part because the crack development produced a rapidly increasing net section stress.

Two of the results reported by CIEMAT used specimens with ground surfaces using a two stage load and temperature method. The first stage was at $0.2 \%$ proof stress and $340{ }^{\circ} \mathrm{C}$. After 528 hours the specimens were inspected by SEM. CIEMAT reported small cracks, although the origins were unclear because of the ground finish. The second stage of the test was performed at a load of $1 \%$ proof stress and $350^{\circ} \mathrm{C}$. Failures were seen after 48 and 192 hours into stage 2 . CIEMAT's third reported initiation time used a $1 \mu \mathrm{m}$ polished specimen and was tested using only the stage 2 load and temperature; this specimen failed after 312 hours.

\section{Heat 2 results}

Heat 2 material (31907) SCC initiation times were reported by six laboratories at test temperatures of 325,350 and $360^{\circ} \mathrm{C}$. The reported initiation times are detailed in Table 3 and Figure 7 (uncorrected for temperature). The data appear to sit in two groups; around half of all specimens tested initiated and cracked within 100 hours of testing. The remaining specimens had longer initiation times of up to about 800 hours (referenced to $325^{\circ} \mathrm{C}$ ). The majority of laboratories only tested specimens from single allocated blocks of material, and in these cases all specimens initiated at very similar times. GE-GRC, however, tested material that exhibited both responses, likely from the different regions, suggesting that the variability was not due to variation in laboratory practices.

Initiation times were readily identified and could be discerned to an accuracy within \pm 20 hours. For this heat multiple large jumps in the DCPD data were often observed and the multiple large SCC cracks formed $(>1 \mathrm{~mm}$ ) on the gauge length of the specimens. Fast crack growth was observed once initiation occurred, leading to specimen failure within around 50 hours from first detection by DCPD if the load was not removed.

\section{Heat 3 results}

Heat 3 material (11415) was tested by five laboratories; two tested at $350{ }^{\circ} \mathrm{C}$ and three at $360{ }^{\circ} \mathrm{C}$. All of the specimens tested showed initiation by DCPD, which was later confirmed by identification of SCC cracks during post-test inspections. The times to initiation were significantly longer than for the previous two heats tested, with initiation times varying between 925 hours $\left(360^{\circ} \mathrm{C}\right)$ and 2,800 hours $\left(350^{\circ} \mathrm{C}\right.$ ) hours. The data are shown in Table 4 and Figure 8 (uncorrected for temperature). The tests performed by Shanghai Jiao Tong University on the heat 3 material reported initiation times ranging between 105 and 1,900 hours by DCPD at $360^{\circ} \mathrm{C}$. It should be noted, when making comparisons with other data, that four 
unmonitored specimens were used, and these initiated within 2,018 hours. Furthermore, the surface condition of the specimens was quite different from the Round-Robin specification. Grit-polished finishes ranging from $180 \#$ to $4000 \#$ were used, and only the $1200 \#$ and the 4000\# finishes may be within the specification. However, with the exception of the very early failure, the results were consistent with the other laboratories. Post-test characterization indicated that cracks on the coarser finished specimens were transgranular through the ground region and often followed machining marks or surface features.

For the post-test characterization on heat 3 specimens, differences in the crack appearance have been reported. Some specimens were observed to have multiple, fine SCC cracks, whereas, on other specimens very large cracks had developed. Those laboratories reporting the presence of finer cracks also observed that the change in gradient of the DCPD response was significantly less than for the other two heats. For the larger cracks the DCPD response was closer to that of the first 2 heats. The time of initiation was discernible to within \pm 150 hours.

\section{DISCUSSION}

\section{Temperature corrections}

Because tests were performed at different temperatures, direct comparison between initiation times is complicated by the effect of temperature. There is the advantage in this Round-Robin exercise that all participants tested at a constant $\triangle \mathrm{ECP}$ from the $\mathrm{Ni} / \mathrm{NiO}$ phase transition boundary. ${ }^{6}$ Therefore, hydrogen effects do not need to be accounted for. To account for the different test temperatures an activation energy of $130 \mathrm{~kJ} / \mathrm{mol}$ was assumed. This value was chosen as it is in the middle of the range identified by Etien et al. ${ }^{6}$ (100 to $170 \mathrm{~kJ} / \mathrm{mol}$ ), similar to that measured by Moss and Was ${ }^{7}$ and used recently by Andresen and Chou. ${ }^{8}$ The $130 \mathrm{~kJ} / \mathrm{mol}$ value is also typically used for Alloy 600 SCC crack growth. ${ }^{6,9-10}$ The data were temperaturecorrected to a common temperature of $350^{\circ} \mathrm{C}$ and are shown for each heat in Figure 9 to Figure 11. This may over-correct for some heats (heats 1 and 2), and under-correct for others (heat 3). However, as will be discussed in the following section, there also appear to be local microstructural variations and effects of temperature that cause different times to initiation in all three heats.

In calculating activation energies for each of the three heats, there is a similar issue with the scatter in results. Using all reported data, the calculated activation energies are 125, 75 and $277 \mathrm{~kJ} / \mathrm{mol}$ for heats 1, 2 and 3, respectively. For the heat 3 data shown in Figure 12, an attempt was made to calculate activation energy for data in two groups shorter and the longer times to initiation. These groups may result from variations in local microstructural differences. Both sets of data indicate an activation energy of $100 \mathrm{~kJ} / \mathrm{mol}$ whereas the data all together give $75 \mathrm{~kJ} / \mathrm{mol}$. Based on data from GE-GRC for heat 1 that was tested at different temperatures, the activation energy is 100 $\mathrm{kJ} / \mathrm{mol}$, Figure 13 . While interesting and suggestive that a single universal activation energy for SCC initiation may not exist for all heats and conditions, the data and temperature sets are limited.

Comparisons among the data obtained at different temperatures will, therefore, be made using $130 \mathrm{~kJ} / \mathrm{mol}$.

\section{Data comparison}

\section{Heat 1}

The initiation times for heat 1 , temperature-corrected to $350^{\circ} \mathrm{C}$, range from 70 to 3,672 hours. Plotting the data cumulative frequency shows that the data can be described by a normal distribution of times (Figure 14 ), with a peak at $\sim 800$ hours. The data at the lower end of the distribution are thought to have been influenced by the presence of the large "balloon" grains in the material microstructure, particularly when orientated into the specimen gauge (Figure 15). These interactions have been reported by both PNNL and WOOD. It has been suggested ${ }^{5}$ that the time to SCC initiation can become longer when an elongated grain intersects the surface with its long axis aligned circumferentially to the specimen gauge. Taking into account this inherent variability in material response, there is a reasonable agreement in the results of all laboratories.

\section{Heat 2}

The initiation times for heat 2, corrected to $350^{\circ} \mathrm{C}$, appear to separate into two groups, and cannot be described by a normal distribution, Figure 16 . Just under $50 \%$ of the data show initiation and rapid failure within 100 hours, and the majority of the remainder of reported initiation times are between 250 and 500 hours. Even the longer initiation times for this heat are relatively short in comparison with heats 1 and 3 . This material initiates readily, and the variability is likely associated with the duplex nature of the microstructure. Within the two groups of initiation times there is good agreement between the laboratories.

\section{Heat 3}

Heat 3 was not tested by as many laboratories (five) as the other materials. Although the data are more limited, the initiation times are clearly longer than for heats 1 and 2 . The initiation times corrected to $350^{\circ} \mathrm{C}$ range from 1,375 to 2,800 hours. There is good agreement between the data generated by GE-GRC, PNNL and Michigan (at 1,500 hours) and Wood and PNNL (at 2,500 hours). There is uncertainty for the initiation times of the uninstrumented SJTU data, but the instrumented data are in agreement with the longer times of Wood and PNNL. The rougher surfaces tested by SJTU do not necessarily lead to higher susceptibility.

Heat 3 is less susceptible to SCC, and the DCPD response as cracks develop was lower than for the first two heats for laboratories that reported fine crack growth. Limited characterization of the tested specimens appears to suggest that a high density of short cracks initiated, but it takes somewhat longer for them to nucleate into a propagating crack. It was noted that there is a bimodal grain size distribution for this material, which may account for the groupings of initiation times, although the data set is relatively small.

\section{Heat to heat comparison}

The three heats of Alloy 600 material tested in this program were all different in their SCC response. The heat 2 material (in the SA, $15 \%$ cold forged condition) was the most susceptible to SCC initiation, and many specimens showed short initiation times of $<100$ hours. This material had a similar tensile strength, hardness, and a variable microstructure to the heat 3 material, but behaved very differently with respect to SCC susceptibility. Microstructurally, heat 2 has a much lower carbon content and larger grain size than for the other two heats.

The heat 1 material (in the MA, $15 \%$ cold forged condition) was less susceptible than heat 2 , but the SCC initiation was much more variable with a normal distribution of initiation times, between 70 and 2,000 hours, with a peak at $\sim 800$ hours. The heat 1 material also showed a variation in tensile properties that led to tests being carried out at somewhat different stresses depending on the laboratory. The observed inhomogeneity of the microstructure (grain size banding, and the presence of large elongated grains) may explain the distribution in results. This variability makes it difficult to assess the influence of other factors that might affect the initiation response. 
The heat 3 material (in the SA, $15 \%$ cold forged condition) was the least susceptible heat, and the progression from initiation to short crack growth was slower. This, too, appeared to show a bimodal response, with initiation times in the vicinity of 1,500 hours or of 2,500 hours, although the data set is much smaller. Initiation times measured for heat 3 were longer than those for the other two heats, and the reasons for this are not clear. It is noted that the heat treatment history is quite different from the other materials, in that it had experienced a thermal treatment prior to the solution annealing. Heats 1 and 2 had not been thermally treated to form grain boundary carbides in this way.

To compare the initiation times for all three heats, with quite different properties and responses to SCC initiation, the initiation times have been plotted against test stress (Figure 17). As the tensile properties of the three heats are different, this plot highlights the range of stresses used in these tests. In addition to the different tensile properties, tests were also performed over a range of applied plastic strains, between 0.2 and $1 \%$.

For heats 1 and 3 the initiation time decreases with increasing stress, albeit with significant scatter. The scatter appears to increase at lower stress. For heat 2, however, the correlation between initiation time and applied stress is not discernible, possibly because of the greater variability in initiation response from specimen to specimen. Plotting the time to initiation data against estimated total strain for all heats (including $15 \%$ cold forging), Figure 18 , shows no discernible relationship.

\section{Methodologies}

The majority of the Round-Robin participants used specimens with dimensions as per the test specification (Figure 1), but there were also some variations. Between the various laboratories there were variations in specimen diameter, which ranged from 2 to $5 \mathrm{~mm}$, and the use of threaded (as opposed to button-ended) specimens. In general, the specimen designs, loading system and grip designs selected by the individual laboratories were determined by the constraints imposed by the specifications of their sponsor's programs. In spite of these variations, the data show no discernible influence of specimen design on the time to initiation. The effect of material variability was significantly higher than any lab-to-lab or methodology variation.

\section{CONCLUSIONS}

This Round-Robin exercise has highlighted the benefits in generating a significant body of data when assessing the susceptibility of a material to stress corrosion cracking. The compilation of data from multiple laboratories using common test techniques greatly assists the understanding of the material variability and gives confidence in the reliability of the results. The development of the Round-Robin test specification provided a benchmark for testing practice and enabled some laboratories new in the field to begin initiation testing to benefit from and compare their data with international contributions.

The microstructural variation within individual specimens appears to be a dominating factor in the initiation response for some materials. This highlights the need to test multiple specimens, especially when the microstructure is inhomogeneous. It is also important to test from multiple locations within a material to obtain the full range of representative results. This study also emphasizes the importance of testing more than one heat for exercises such as this, as otherwise it may be concluded that some observations were due to variation in laboratory practices, as opposed to material variability.
The main conclusions are:

- The test method has been shown to be very good at providing real-time detection of stress corrosion crack initiation and has been applied successfully in multiple laboratories making it a suitable guideline for initiation tests.

- A large variation in initiation times was observed between the different materials, and also a large variation within some materials, highlighting the role of inhomogeneity of microstructures.

- It is important to carry out multiple tests to ensure that variability within a heat is assessed.

- $\quad$ Further data on specimen locations and microstructures may reveal an improved understanding of initiation response.

- $\quad$ Lab-to-lab variability and specimen design among the participants are less of an influence on results than material inhomogeneity.

\section{ACKNOWLEDGEMENT}

The authors would like to gratefully acknowledge the support and contribution to this Round-Robin exercise from the following members of the ICG-EAC: Stuart Medway (Jacobs), Steve Bruemmer (PNNL), Gary Was (University of Michigan), Ulla Ehrnstén (VTT), Raj Pathania (EPRI), Hans-Peter Seifert (PSI), Tony Horner (Rolls-Royce) and Ziqing Zhai (PNNL).

The financial support by the following organizations is also acknowledged: Electric Power Research Institute (EPRI), University of Michigan, Swiss Federal Nuclear Safety Inspectorate (ENSI), Swedish Radiation Safety Authority, Ringhals $A B$, Forsmarks Kraftgrupp $A B$, Oskarshamns Kraft AB, Studsvik Nuclear $A B$, The National Natural Science Foundation of China, UJV, Project THELMA of the Finnish national nuclear power plant safety program SAFIR2018, CEIMAT and the U.S. Department of Energy LWRS Program. 


\section{REFERENCES}

1. G.S. Was, K. Lian, Corrosion 54, 9 (1998): p. 675-688.

2. S.M. Bruemmer, L.A. Charlot, C.H. Henage Jr., Corrosion 44, 11 (1988): p. 782-788.

3. E. Richey, D.S. Morton, R.A. Etien, "SCC Initiation Testing of NickelBased Alloys in High Temperature Water," $13^{\text {th }}$ International Conference on Environmental Degradation of Materials in Nuclear Power Systems, EDM13 P0066 (Toronto, Canada: Canadian Nuclear Society, 2007).

4. Z. Zhai, M. Toloczko, S. Bruemmer, "Microstructural Effects on SCC Initiation in PWR Primary Water for Cold-Worked Alloy 600," $18^{\text {th }}$ International Conference on Environmental Degradation of Materials in Nuclear Power Systems-Water Reactors (Warrendale, PA: The Minerals, Metals \& Materials Society, 2017), p. 217-229.

5. Z. Zhai, M.B. Toloczko, M.J. Olszta, D.K. Schreiber, S.M. Bruemmer, "Stress Corrosion Crack Initiation of Alloy 600 in Simulated PWR Primary Water," DOE Office of Nuclear Energy, Technical Milestone Report M2LW-17OR0402034, Light Water Reactor Sustainability Program, September 2017.

6. R.A. Etien, E. Richey, D.S. Morton, J. Eager, "SCC Initiation Testing Of Alloy 600 In High Temperature Water," $15^{\text {th }}$ International Conference on Environmental Degradation of Materials in Nuclear Power Systems-Water Reactors (Warrendale, PA: The Minerals, Metals \& Materials Society, 2011).

7. T. Moss, G.S. Was, "Accelerated Stress Corrosion Crack Initiation of Alloy 690 and Alloy 600 in High Temperature Hydrogenated Water," $16^{\text {th }}$ International Conference on Environmental Degradation of Materials in Nuclear Power Systems-Water Reactors (Houston, TX: NACE International, 2013).

8. P. Andresen, P. Chou, "Crack Initiation of Alloy 600 in PWR Water," $18^{\text {th }}$ International Conference on Environmental Degradation of Materials in Nuclear Power Systems-Water Reactors (Warrendale, PA: The Minerals, Metals \& Materials Society, 2017), p. 121.

9. E. Richey, D.S. Morton, M.K. Schurman, "SCC Initiation Testing of Nickel-Based Alloys Using In-Situ Monitored Uniaxial Tensile Specimens," $12^{\text {th }}$ International Conference on Environmental Degradation of Materials in Nuclear Power Systems-Water Reactors (Warrendale, PA: The Minerals, Metals \& Materials Society, 2005).

10. E. Richey, D.S. Morton, R.A. Etien, "SCC Initiation Testing of Nickel-Based Alloys in High Temperature Water," $13^{\text {th }}$ Conference on Environmental Degradation of Materials in Nuclear Power Systems-Water Reactors (Toronto, Canada: Canadian Nuclear Society, 2007). 
TABLES

Table 1: Summary of material composition (\% wt) for each of the three heats tested

\begin{tabular}{|c|c|c|c|c|c|c|c|c|c|c|c|c|c|}
\hline Material & C & Si & Mn & $\mathrm{Cr}$ & $\mathrm{Ni}$ & $\mathbf{S}$ & $\mathbf{P}$ & $\mathrm{Fe}$ & Mo & Co & $\mathrm{Cu}$ & Al & B $($ appm*) \\
\hline HEAT 1 & 0.060 & 0.22 & 0.23 & 16.36 & 74.0 & 0.001 & 0.004 & 8.5 & - & 0.030 & 0.01 & 0.223 & 83 \\
\hline \multicolumn{14}{|l|}{ PNNL } \\
\hline \multicolumn{14}{|l|}{ NX6106KX } \\
\hline HEAT 2 & 0.01 & 0.22 & 0.46 & 15.6 & 75.1 & 0.0002 & 0.0092 & 7.92 & 0.03 & 0.011 & $<0.01$ & 0.22 & 46 \\
\hline \multicolumn{14}{|l|}{ EPRI } \\
\hline \multicolumn{14}{|l|}{31907} \\
\hline HEAT 3 & 0.036 & 0.20 & 0.20 & 15.53 & 74.62 & 0.001 & 0.005 & 8.87 & - & 0.03 & 0.03 & 0.27 & 1.7 \\
\hline \multicolumn{14}{|l|}{ Rolls-Royce } \\
\hline RR-A600 & & & & & & & & & & & & & \\
\hline
\end{tabular}

*The $\mathrm{B}$ content is measured by glow discharge mass spectrometry ${ }^{2}$

Table 2: Summary of heat 1 initiation results

\begin{tabular}{|c|c|c|c|c|c|c|}
\hline & $\begin{array}{l}\text { Applied } \\
\text { Stress }\end{array}$ & $\begin{array}{l}\text { Applied } \\
\text { Strain }\end{array}$ & $\begin{array}{c}\text { Test } \\
\text { Temperature }\end{array}$ & $\begin{array}{c}\text { Reported } \\
\text { Initiation } \\
\text { Time }\end{array}$ & $\begin{array}{l}\text { Time } \\
\text { Corrected } \\
\text { to } 350^{\circ} \mathrm{C} \\
\text { using } \\
130 \mathrm{~kJ} / \mathrm{mol}\end{array}$ & Comments \\
\hline & $\mathrm{MPa}$ & $\%$ & C & Hours & Hours & \\
\hline Wood & 600 & 15.6 & 350 & 535 & 535 & \\
\hline Wood & 600 & 15.6 & 350 & 587 & - & Run Out \\
\hline Wood & 600 & 15.6 & 350 & 587 & - & Run Out \\
\hline GE & 505 & 15.0 & 360 & 1,037 & 1,542 & \\
\hline GE & 505 & 15.0 & 360 & 1,108 & 1,647 & \\
\hline GE & 505 & 15.0 & 360 & 372 & 553 & \\
\hline GE & 505 & 15.0 & 360 & 541 & 804 & \\
\hline GE & 505 & 15.0 & 360 & 817 & 1,215 & \\
\hline GE & 505 & 15.0 & 360 & 506 & 752 & \\
\hline GE & 505 & 15.0 & 360 & 1,350 & - & Run Out \\
\hline GE & 505 & 15.0 & 360 & 1,350 & - & Run Out \\
\hline GE & 550 & 15.0 & 325 & 2243 & 785 & \\
\hline GE & 550 & 15.0 & 325 & 2,243 & 785 & \\
\hline GE & 550 & 15.0 & 325 & 1,625 & 569 & \\
\hline GE & 550 & 15.0 & 325 & 2,243 & 785 & \\
\hline
\end{tabular}




\begin{tabular}{|c|c|c|c|c|c|c|}
\hline & $\begin{array}{l}\text { Applied } \\
\text { Stress }\end{array}$ & $\begin{array}{l}\text { Applied } \\
\text { Strain }\end{array}$ & $\begin{array}{c}\text { Test } \\
\text { Temperature }\end{array}$ & $\begin{array}{c}\text { Reported } \\
\text { Initiation } \\
\text { Time }\end{array}$ & $\begin{array}{l}\text { Time } \\
\text { Corrected } \\
\text { to } 350^{\circ} \mathrm{C} \\
\text { using } \\
130 \mathrm{~kJ} / \mathrm{mol}\end{array}$ & Comments \\
\hline & $\mathrm{MPa}$ & $\%$ & C & Hours & Hours & \\
\hline GE & 550 & 15.0 & 325 & 2,243 & - & Run Out \\
\hline GE & 550 & 15.0 & 325 & 2,243 & - & Run Out \\
\hline GE & 550 & 15.0 & 325 & 2,243 & - & Run Out \\
\hline GE & 550 & 15.0 & 325 & 2,243 & - & Run Out \\
\hline PNNL & 550 & 15.2 & 360 & 396 & 589 & \\
\hline PNNL & 550 & 15.2 & 360 & 385 & 572 & \\
\hline PNNL & 550 & 15.2 & 360 & 219 & 326 & \\
\hline Michigan & 572 & 15.2 & 350 & 271 & 271 & \\
\hline Michigan & 550 & 15.2 & 350 & 830 & 830 & \\
\hline Michigan & 550 & 15.2 & 350 & 857 & 857 & \\
\hline PSI & 600 & 15.7 & 350 & 310 & 310 & \\
\hline PSI & 600 & 15.7 & 350 & 261 & 261 & \\
\hline PSI & 600 & 15.7 & 350 & 120 & 120 & \\
\hline PSI & 600 & 15.7 & 350 & 70 & 70 & \\
\hline UJV & 540 & 16.0 & 320 & 4,800 & - & Run Out \\
\hline SJTU & 570 & 15.2 & 360 & 215 & 320 & $\begin{array}{l}\text { Times by } \\
\text { inspection }\end{array}$ \\
\hline SJTU & 570 & 15.2 & 360 & 215 & 320 & $\begin{array}{l}\text { Times by } \\
\text { inspection }\end{array}$ \\
\hline SJTU & 570 & 15.2 & 360 & 2,470 & 3,672 & $\begin{array}{l}\text { Times by } \\
\text { inspection }\end{array}$ \\
\hline SJTU & 570 & 15.2 & 360 & 253 & 376 & $\begin{array}{l}\text { Times by } \\
\text { inspection }\end{array}$ \\
\hline SJTU & 570 & 15.2 & 360 & 888 & 1,320 & $\begin{array}{l}\text { Times by } \\
\text { inspection }\end{array}$ \\
\hline SJTU & 570 & 15.2 & 360 & 1,345 & 1,999 & $\begin{array}{l}\text { Times by } \\
\text { inspection }\end{array}$ \\
\hline Studsvik & 512 & 15.0 & 350 & 810 & 810 & \\
\hline Studsvik & 512 & 15.0 & 350 & 1,095 & 1,095 & \\
\hline Studsvik & 522 & 15.0 & 350 & 1,220 & 1,220 & \\
\hline Studsvik & 524 & 15.0 & 350 & 1368 & 1368 & \\
\hline
\end{tabular}




\begin{tabular}{|c|c|c|c|c|c|c|}
\hline & $\begin{array}{l}\text { Applied } \\
\text { Stress }\end{array}$ & $\begin{array}{l}\text { Applied } \\
\text { Strain }\end{array}$ & $\begin{array}{c}\text { Test } \\
\text { Temperature }\end{array}$ & $\begin{array}{c}\text { Reported } \\
\text { Initiation } \\
\text { Time }\end{array}$ & $\begin{array}{c}\text { Time } \\
\text { Corrected } \\
\text { to } 350^{\circ} \mathrm{C} \\
\text { using } \\
130 \mathrm{~kJ} / \mathrm{mol}\end{array}$ & Comments \\
\hline & $\mathrm{MPa}$ & $\%$ & C & Hours & Hours & \\
\hline Ciemat & See note & See note & $340+350$ & $\begin{array}{c}528+192 \\
(720)\end{array}$ & $\begin{array}{c}351+192 \\
(543)\end{array}$ & $\begin{array}{c}\text { Stage 1: 340C } \\
0.2 \% \text { YS (520 } \\
\text { Mpa) } \\
\text { Stage 2: } 350 \mathrm{C} \\
\text { 1\% Proof } \\
(620 \mathrm{MPa})\end{array}$ \\
\hline Ciemat & See note & See note & $340+350$ & $\begin{array}{c}528+48 \\
(576)\end{array}$ & $\begin{array}{c}351+48 \\
(399)\end{array}$ & $\begin{array}{c}\text { Stage 1: } 340 \mathrm{C} \\
0.2 \% \text { YS (520 } \\
\text { Mpa) } \\
\text { Stage 2: } 350 \mathrm{C} \\
\text { 1\% Proof } \\
(620 \mathrm{MPa})\end{array}$ \\
\hline Ciemat & 620 & 16.0 & 350 & 312 & 312 & $\begin{array}{l}1 \% \text { Proof } 620 \\
\mathrm{MPa}\end{array}$ \\
\hline
\end{tabular}

Table 3: Summary of heat 2 initiation results

\begin{tabular}{|c|c|c|c|c|c|c|}
\hline & $\begin{array}{l}\text { Applied Stress } \\
\text { (MPa) }\end{array}$ & $\begin{array}{l}\text { Applied Strain } \\
\text { (\%) }\end{array}$ & $\begin{array}{l}\text { Test Temperature } \\
\left({ }^{\circ} \mathrm{C}\right)\end{array}$ & $\begin{array}{c}\text { Reported } \\
\text { Initiation Time } \\
\text { (hours) }\end{array}$ & $\begin{array}{c}\text { Time (hours) } \\
\text { Corrected to } \\
350^{\circ} \mathrm{C} \text { using } \\
130 \mathrm{~kJ} / \mathrm{mol}\end{array}$ & Comments \\
\hline Wood & 394 & 16.0 & 350 & 40 & 40 & \\
\hline Wood & 394 & 15.8 & 350 & 30 & 30 & \\
\hline Wood & 394 & 16.2 & 350 & 40 & 40 & \\
\hline GE & 377 & 15.0 & 360 & 467 & 694 & \\
\hline GE & 377 & 15.0 & 360 & 473 & 703 & \\
\hline GE & 377 & 15.0 & 360 & 220 & 327 & \\
\hline GE & 377 & 15.0 & 360 & 36 & 54 & \\
\hline GE & 377 & 15.0 & 360 & 25 & 37 & \\
\hline GE & 355 & 15.0 & 325 & 84 & 29 & \\
\hline GE & 355 & 15.0 & 325 & 143 & 50 & \\
\hline GE & 355 & 15.0 & 325 & 375 & 131 & \\
\hline GE & & 15.0 & 325 & 813 & - & Run Out \\
\hline GE & 355 & 15.0 & 325 & 143 & 50 & \\
\hline PNNL & 350 & 15.2 & 360 & 295 & 439 & \\
\hline PNNL & 350 & 15.2 & 360 & 351 & 522 & \\
\hline PNNL & 350 & 15.2 & 360 & 368 & 547 & \\
\hline PNNL & 355 & 15.2 & 325 & 1,240 & 434 & \\
\hline
\end{tabular}




\begin{tabular}{|c|c|c|c|c|c|c|}
\hline & $\begin{array}{l}\text { Applied Stress } \\
\text { (MPa) }\end{array}$ & $\begin{array}{c}\text { Applied Strain } \\
\text { (\%) }\end{array}$ & $\begin{array}{l}\text { Test Temperature } \\
\qquad\left({ }^{\circ} \mathrm{C}\right)\end{array}$ & $\begin{array}{c}\text { Reported } \\
\text { Initiation Time } \\
\text { (hours) }\end{array}$ & $\begin{array}{c}\text { Time (hours) } \\
\text { Corrected to } \\
350^{\circ} \mathrm{C} \text { using } \\
130 \mathrm{~kJ} / \mathrm{mol}\end{array}$ & Comments \\
\hline PNNL & 355 & 15.2 & 325 & 1,350 & 473 & \\
\hline PNNL & 355 & 15.2 & 325 & 1,080 & 378 & \\
\hline Michigan & 356 & 15.2 & 350 & 81 & 81 & \\
\hline Michigan & 374 & 15.2 & 350 & 73 & 73 & \\
\hline VTT & 377 & 16.0 & 350 & 260 & 260 & \\
\hline VTT & 380 & 16.0 & 350 & 510 & 510 & \\
\hline SJTU & 383 & 15.1 & 360 & 69 & 103 & cracked, DCPD \\
\hline SJTU & 405 & 15.7 & 360 & 52 & 77 & $\begin{array}{c}\text { specimen failed, no } \\
\text { DCPD }\end{array}$ \\
\hline SJTU & 383 & 15.1 & 360 & 152 & 226 & cracked, DCPD \\
\hline SJTU & 405 & 15.7 & 360 & 31 & 46 & $\begin{array}{c}\text { specimen failed, no } \\
\text { DCPD }\end{array}$ \\
\hline SJTU & 383 & 15.1 & 360 & 578 & 859 & cracked, DCPD \\
\hline SJTU & 383 & 15.1 & 360 & 135 & 201 & cracked, DCPD \\
\hline
\end{tabular}

Table 4: Summary of heat 3 initiation results

\begin{tabular}{|c|c|c|c|c|c|c|}
\hline & $\begin{array}{l}\text { Applied Stress } \\
\text { (MPa) }\end{array}$ & $\begin{array}{l}\text { Applied Strain } \\
\text { (\%) }\end{array}$ & $\begin{array}{l}\text { Test Temperature } \\
\left({ }^{\circ} \mathrm{C}\right)\end{array}$ & $\begin{array}{c}\text { Reported Initiation } \\
\text { Time } \\
\text { (hours) }\end{array}$ & $\begin{array}{l}\text { Time (hours) } \\
\text { Corrected to } 350 \mathrm{C} \\
\text { using } 130 \mathrm{~kJ} / \mathrm{mol}\end{array}$ & Comments \\
\hline Wood & 440 & 15.6 & 350 & 2,800 & 2,800 & \\
\hline Wood & 440 & 15.6 & 350 & 2,600 & 2,600 & \\
\hline Wood & 440 & 16.1 & 350 & 2,200 & 2,200 & \\
\hline GE & 403 & 15.0 & 360 & 925 & 1,375 & \\
\hline GE & 403 & 15.0 & 360 & 960 & 1,427 & \\
\hline GE & 403 & 15.0 & 360 & 1,005 & 1,494 & \\
\hline GE & 403 & 15.0 & 360 & 1,040 & 1,546 & \\
\hline GE & 403 & 15.0 & 360 & 1,075 & 1,598 & \\
\hline PNNL & 416 & 15.2 & 360 & 1,090 & 1,620 & \\
\hline PNNL & 421 & 15.2 & 360 & 1,028 & 1,528 & \\
\hline PNNL & 412 & 15.2 & 360 & 1,710 & 2,542 & \\
\hline Michigan & 448 & 15.2 & 350 & 1,463 & 1,463 & \\
\hline
\end{tabular}




\begin{tabular}{|c|c|c|c|c|c|c|}
\hline SJTU & 403 & 1.08 YS & 360 & 105 & 156 & $\begin{array}{l}\text { cracked, DCPD, } \\
\text { 180\# polished } \\
\text { (rough) }\end{array}$ \\
\hline SJTU & 403 & $1.08 \mathrm{YS}$ & 360 & 2,018 & 3,000 & $\begin{array}{l}\text { No DCPD initiated } \\
\text { within } 2018 \text { h, 180\# } \\
\text { polished (rough) }\end{array}$ \\
\hline SJTU & 403 & $1.08 \mathrm{YS}$ & 360 & 2,018 & 3,000 & $\begin{array}{l}\text { No DCPD initiated } \\
\text { within } 2018 \mathrm{~h}, 4000 \# \\
\text { polished }\end{array}$ \\
\hline SJTU & 403 & 1.08 YS & 360 & 1,900 & 2,825 & $\begin{array}{c}\text { cracked, DCPD, } \\
400 \# \text { polished }\end{array}$ \\
\hline SJTU & 403 & 1.08 YS & 360 & 2,018 & 3,000 & $\begin{array}{l}\text { No DCPD initiated } \\
\text { within } 2018 \text { h, 400\# } \\
\text { polished }\end{array}$ \\
\hline SJTU & 403 & 1.08 YS & 360 & 2,018 & 3,000 & $\begin{array}{c}\text { No DCPD initiated } \\
\text { within } 2018 \text { h, } 1200 \# \\
\text { polished }\end{array}$ \\
\hline
\end{tabular}



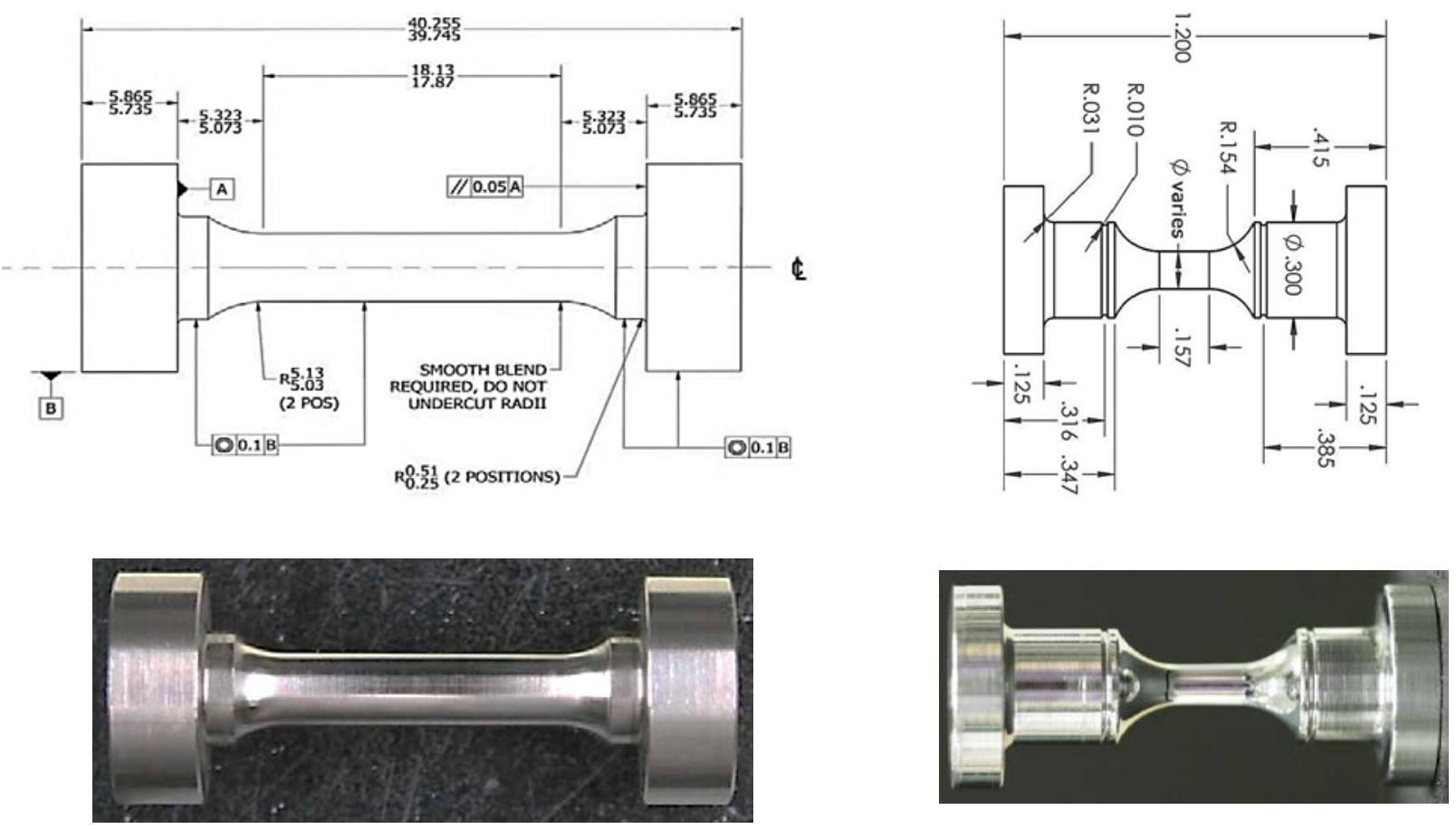

Figure 1: Button-ended specimen and specimen with reference section.

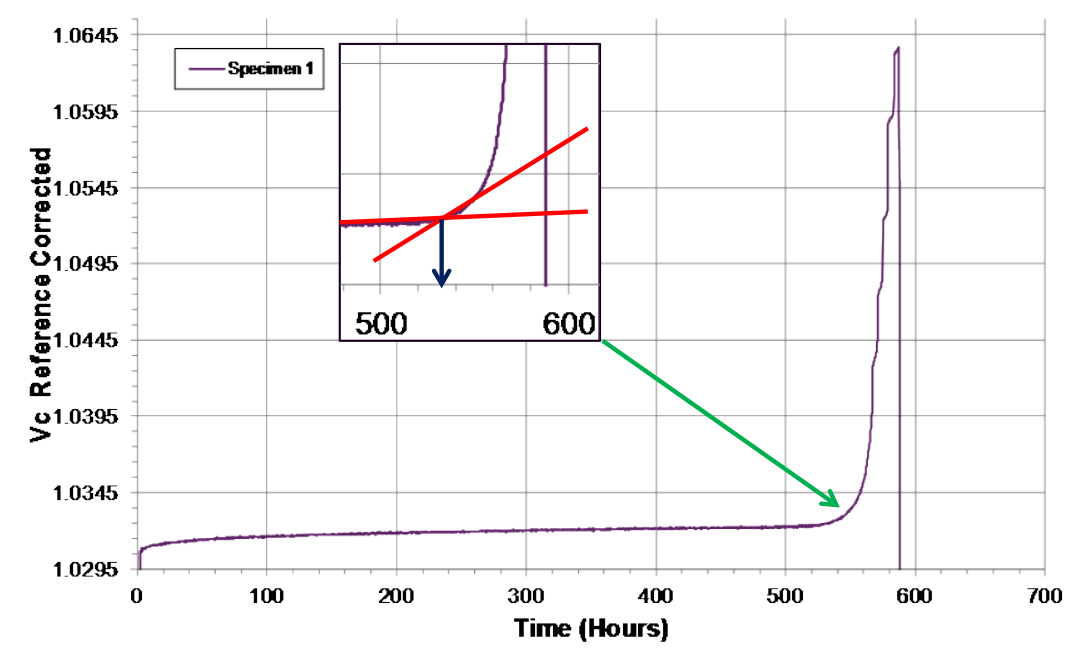

Figure 2: Example DCPD response showing inflection when short cracks coalesce into a propagating SCC crack. (the inflection point is where the gradient changes, the steeper red line is for illustrating the change of gradient only)
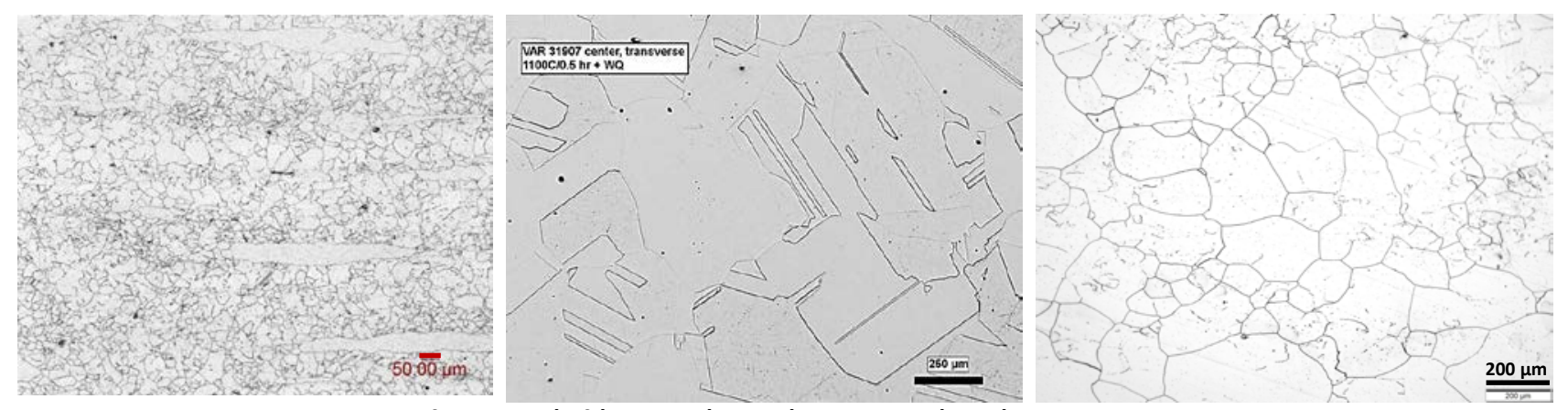

Figure 3: Example microstructures for heat 1 (left), heat 2 (center) and heat 3 (right). 

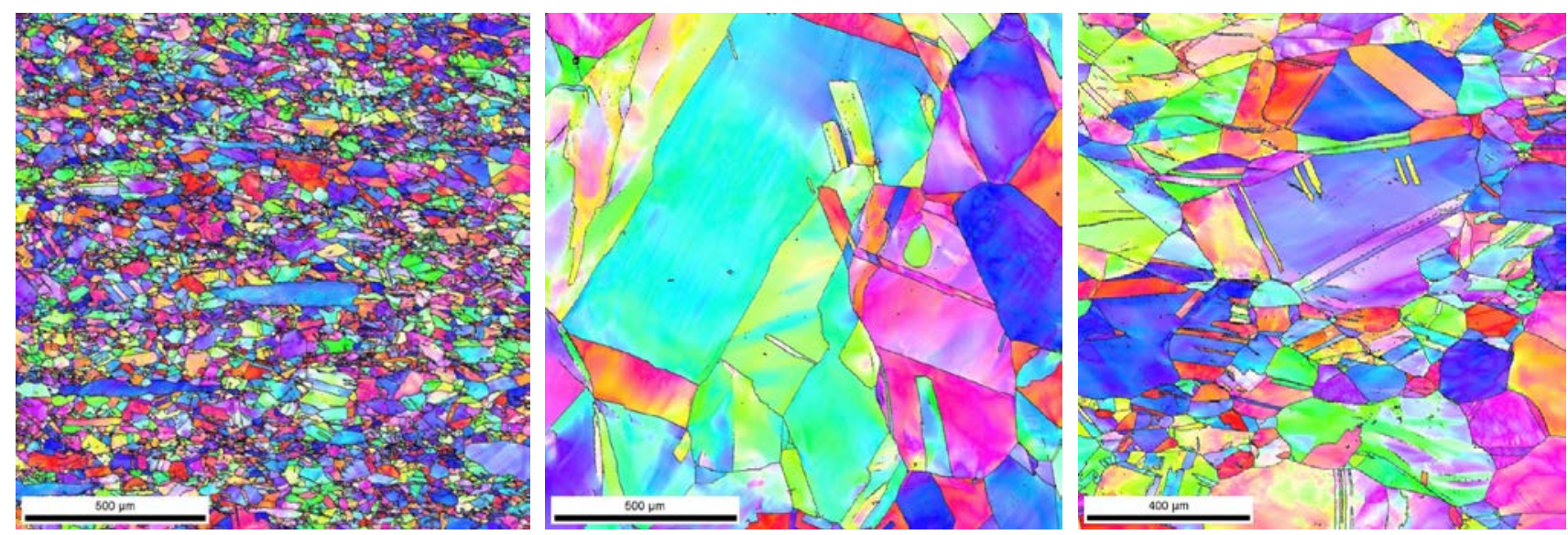

Figure 4: EBSD Inverse Pole Figures showing examples of microstructure and grain orientations for heat 1 (left), heat 2 (centre) and heat 3 (right).

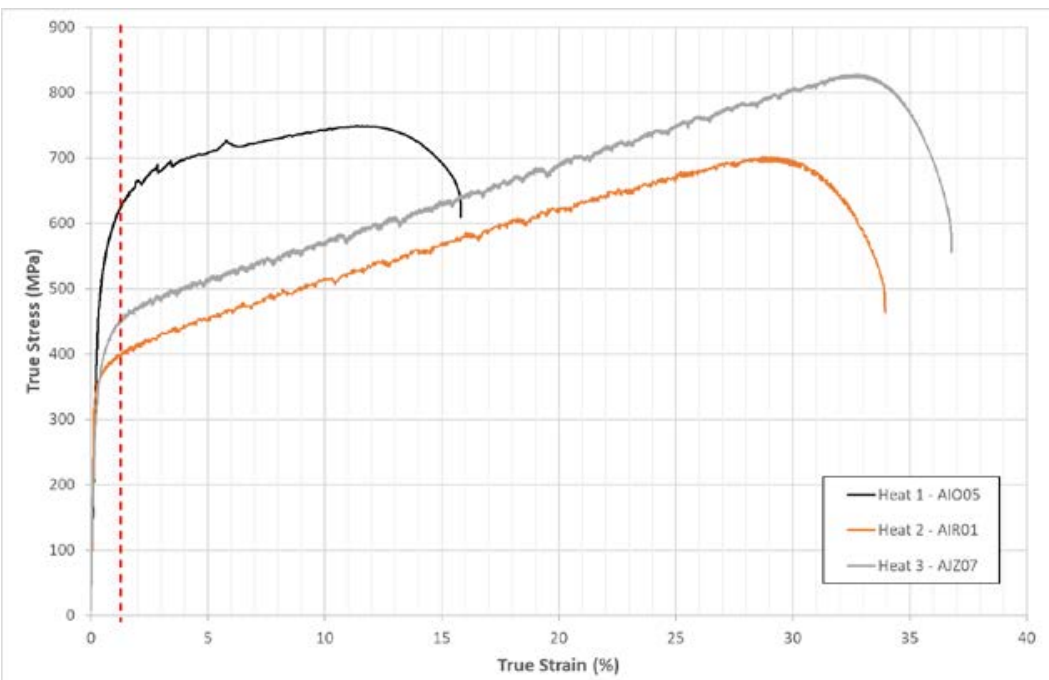

Figure 5: Tensile data (true stress vs true strain) for all material heats. Dotted line at $1 \%$ true strain highlights target test strain (measured at $350^{\circ} \mathrm{C}$ in air). 


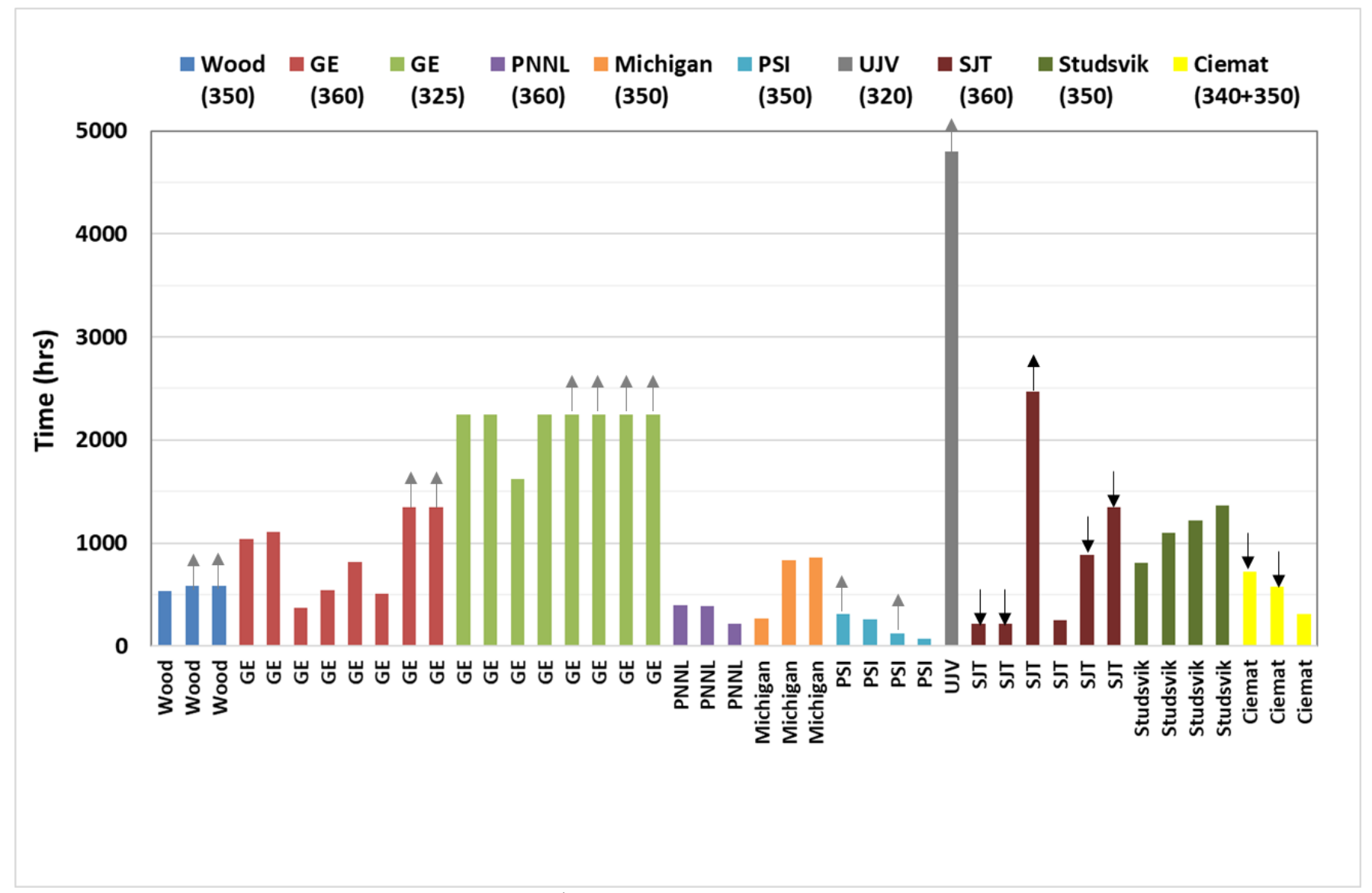

Figure 6: Heat 1 SCC initiation data including run outs $(\uparrow)$ and for interrupted tests where initiation occurred before stated time $(\downarrow)$. 


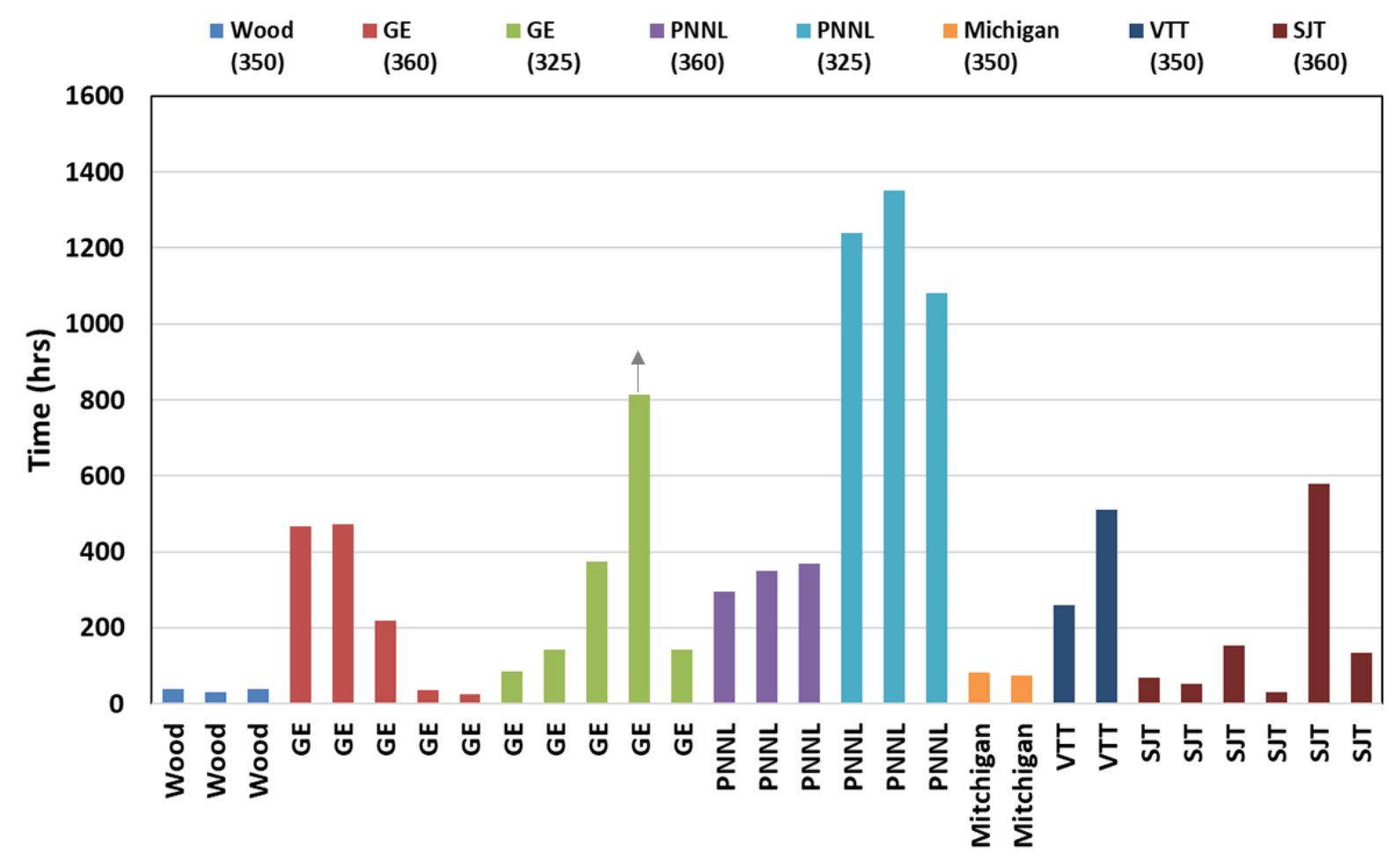

Figure 7: Heat 2 SCC initiation data including run outs ( $)$.

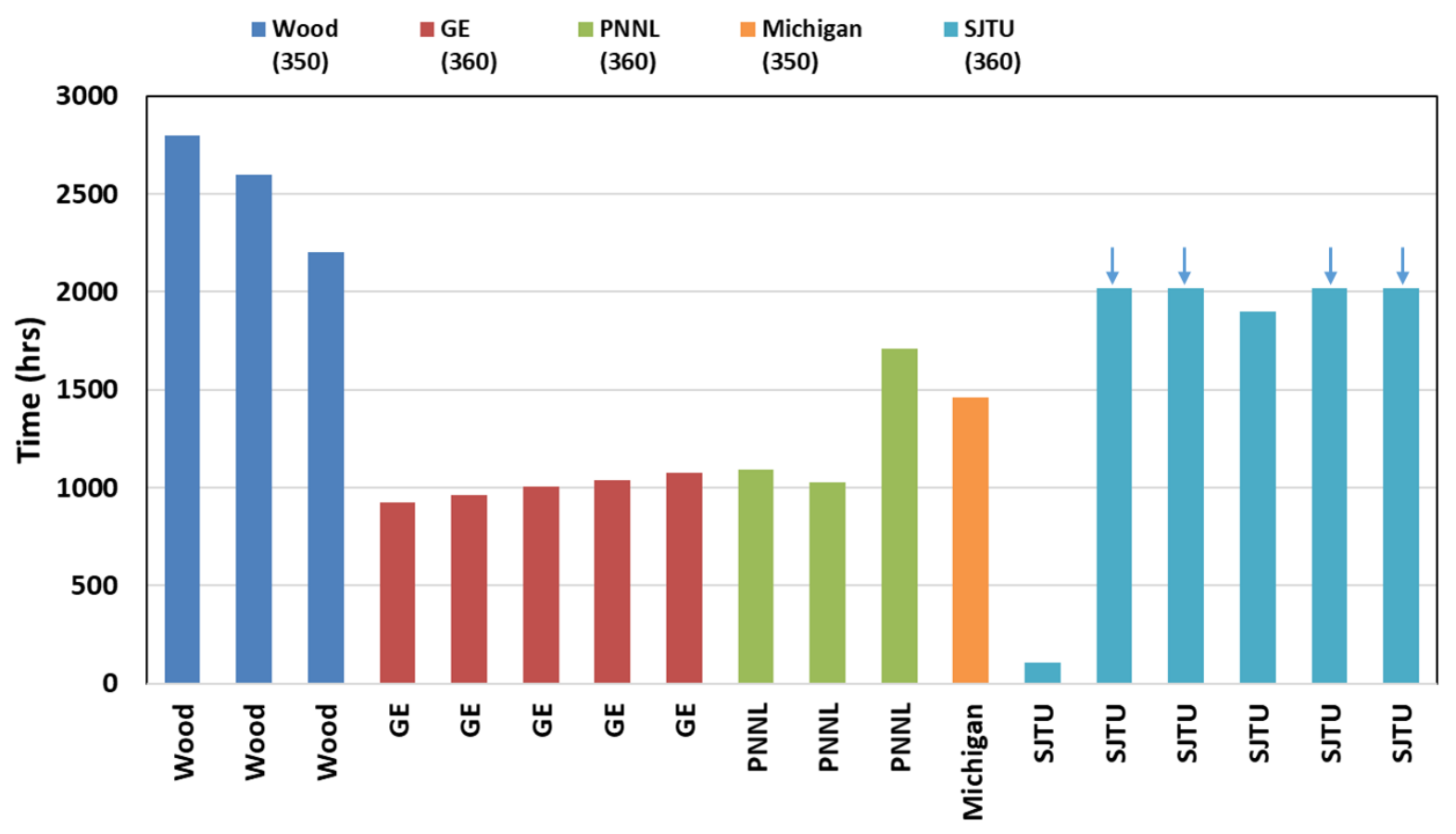




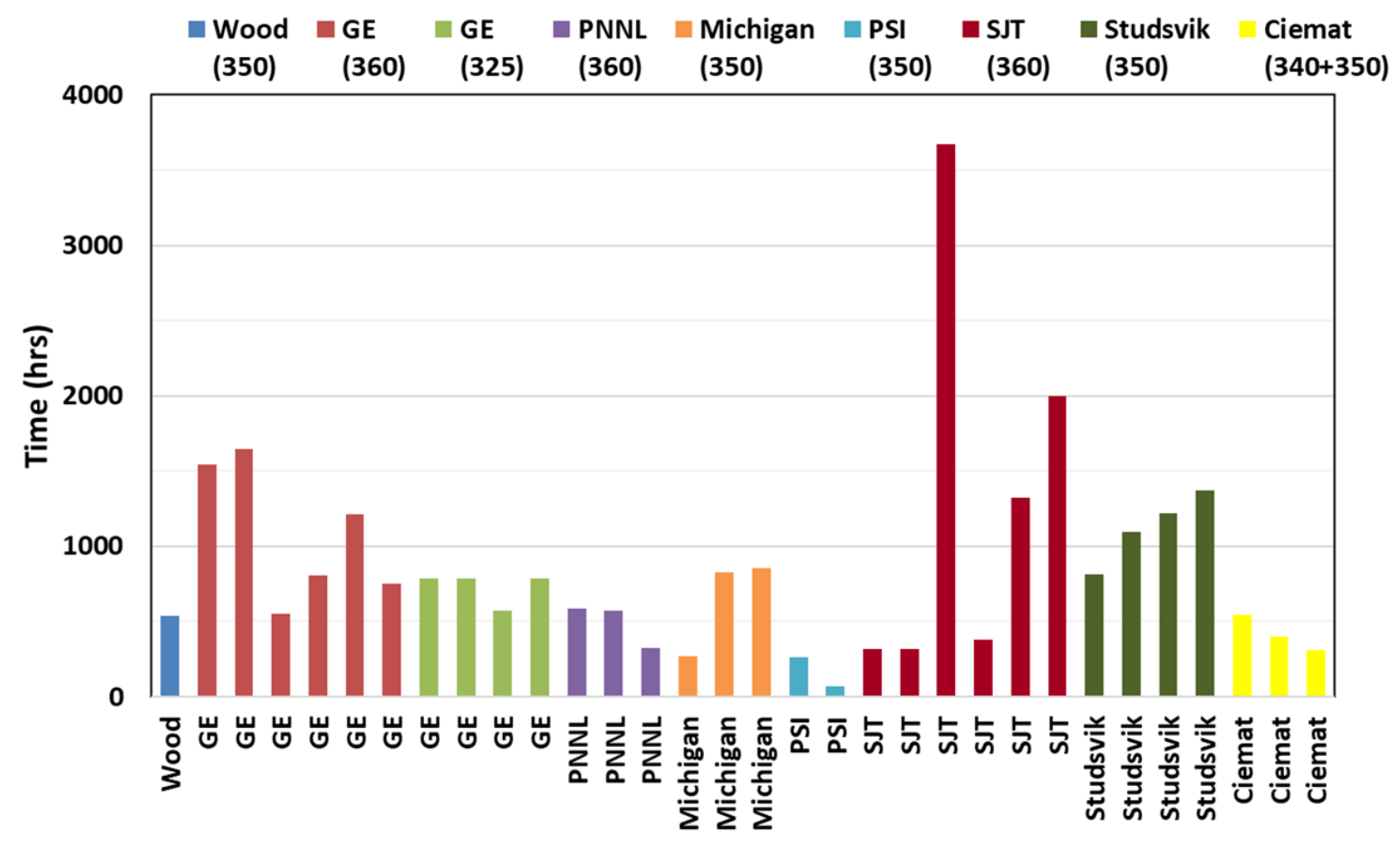

Figure 9: Heat $1 \mathrm{SCC}$ initiation data corrected to $350^{\circ} \mathrm{C}$ using an activation energy of $130 \mathrm{~kJ} / \mathrm{mol}$.

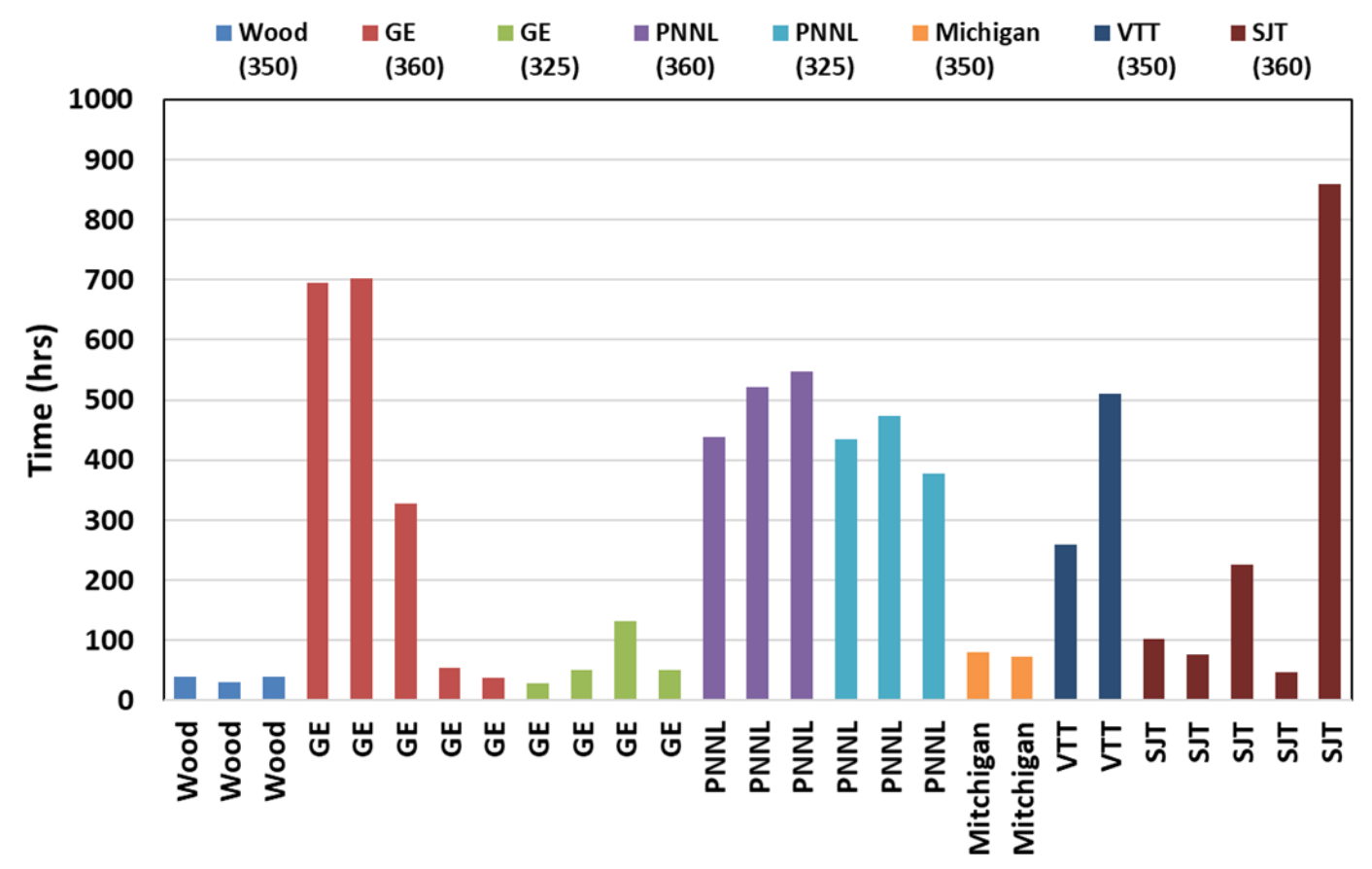

Figure 10: Heat $2 \mathrm{SCC}$ initiation data corrected to $350^{\circ} \mathrm{C}$ using an activation energy of $130 \mathrm{~kJ} / \mathrm{mol}$. 


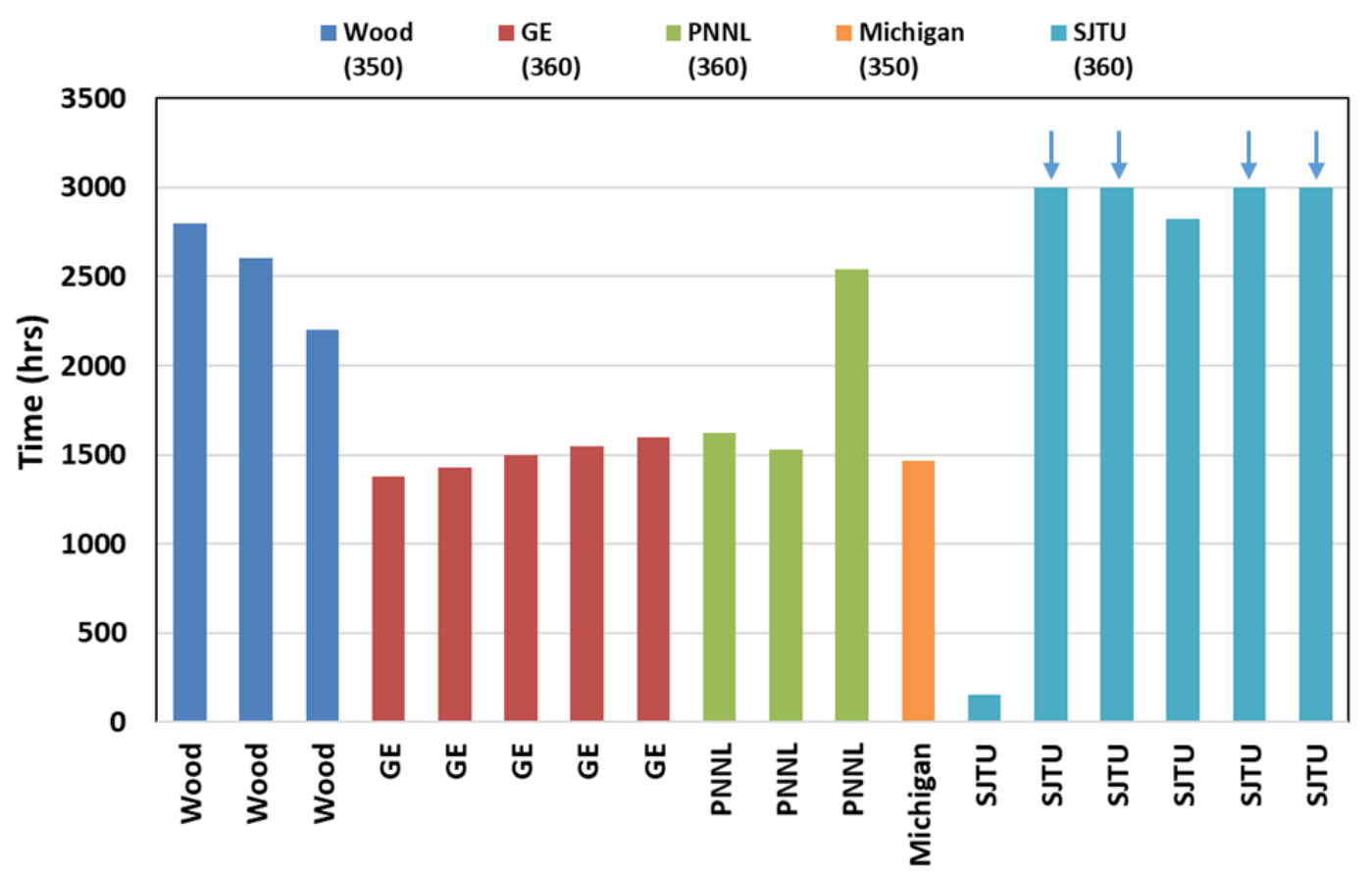

Figure 11: Heat $3 \mathrm{SCC}$ initiation data corrected to $350^{\circ} \mathrm{C}$ using an activation energy of $130 \mathrm{~kJ} / \mathrm{mol}$.

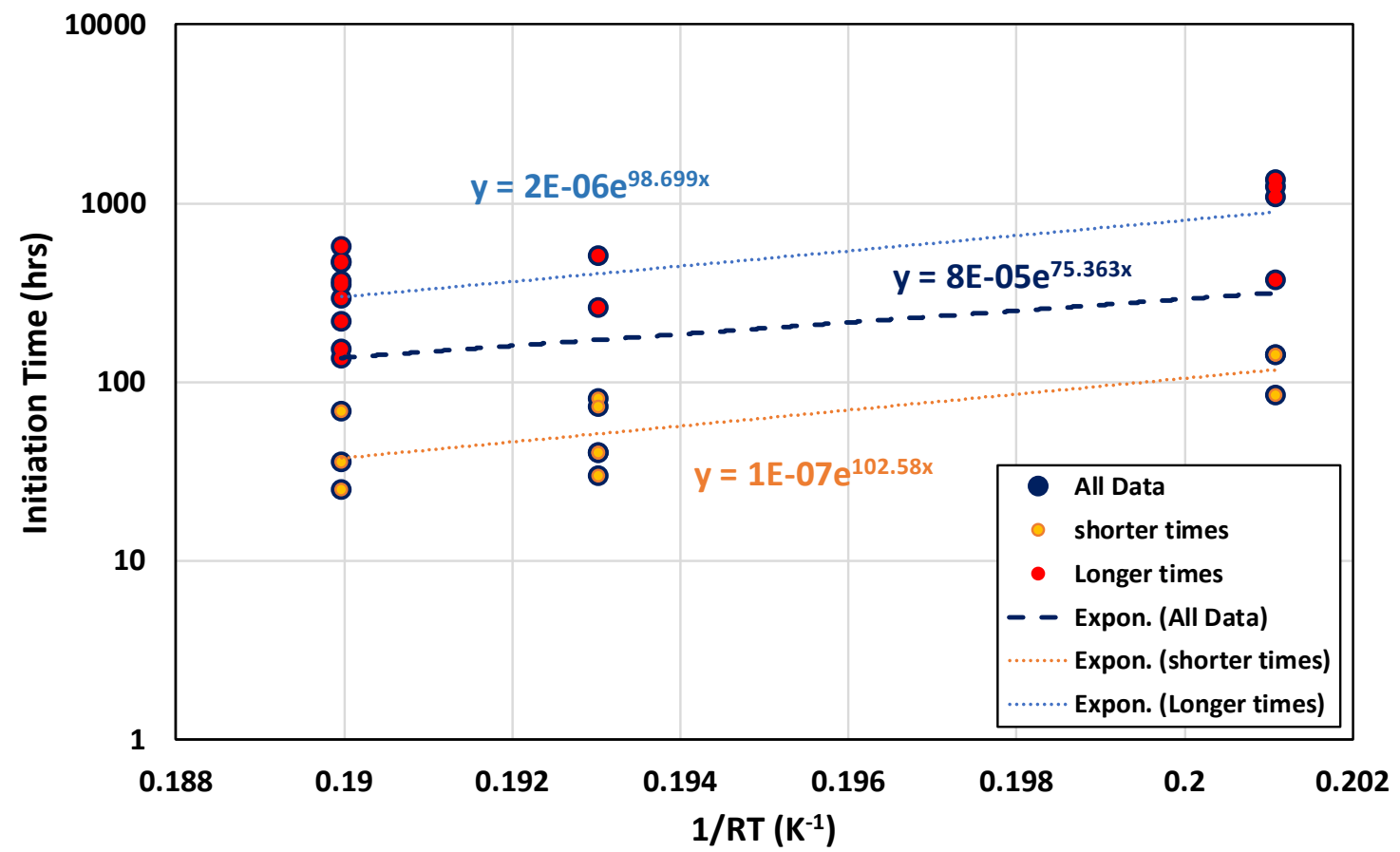

Figure 12: Activation energy calculations for heat 2. Using all data is shown in heavy dark blue (75 $\mathrm{kJ} / \mathrm{mol})$, using the higher rates in light blue $(99 \mathrm{~kJ} / \mathrm{mol})$ and the lower rates in orange $(103 \mathrm{~kJ} / \mathrm{mol})$. 


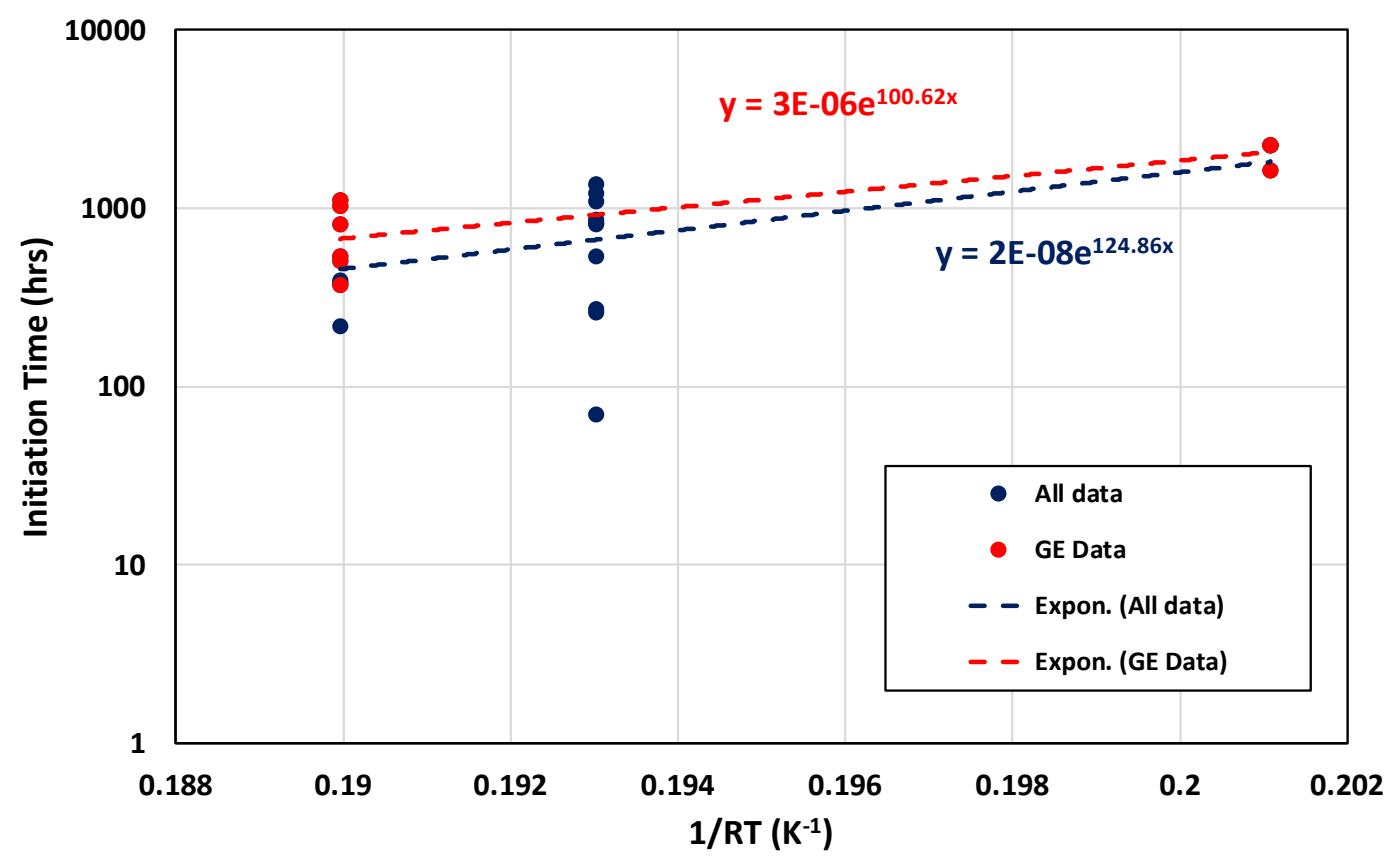

Figure 13: Activation energy calculations for heat 1 . Using all data is shown in blue (125 kJ/mol) and a single subset from GE_GRC in red $(101 \mathrm{~kJ} / \mathrm{mol})$.
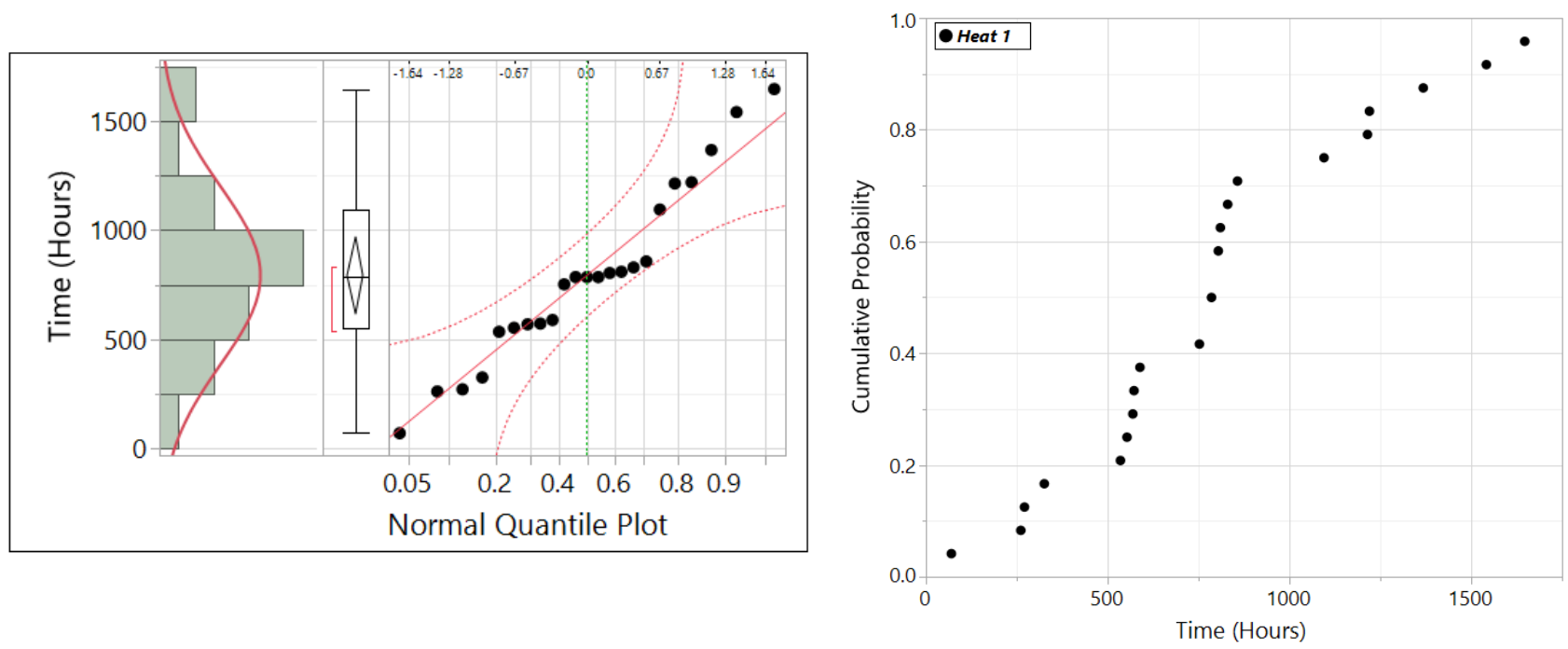

Figure 14: Data frequency and distributions of initiation times for heat 1. Both plots illustrate the increase in cumulative probability of crack initiation as exposure time increases; $50 \%$ probability corresponds to an exposure time of 800 hours. 


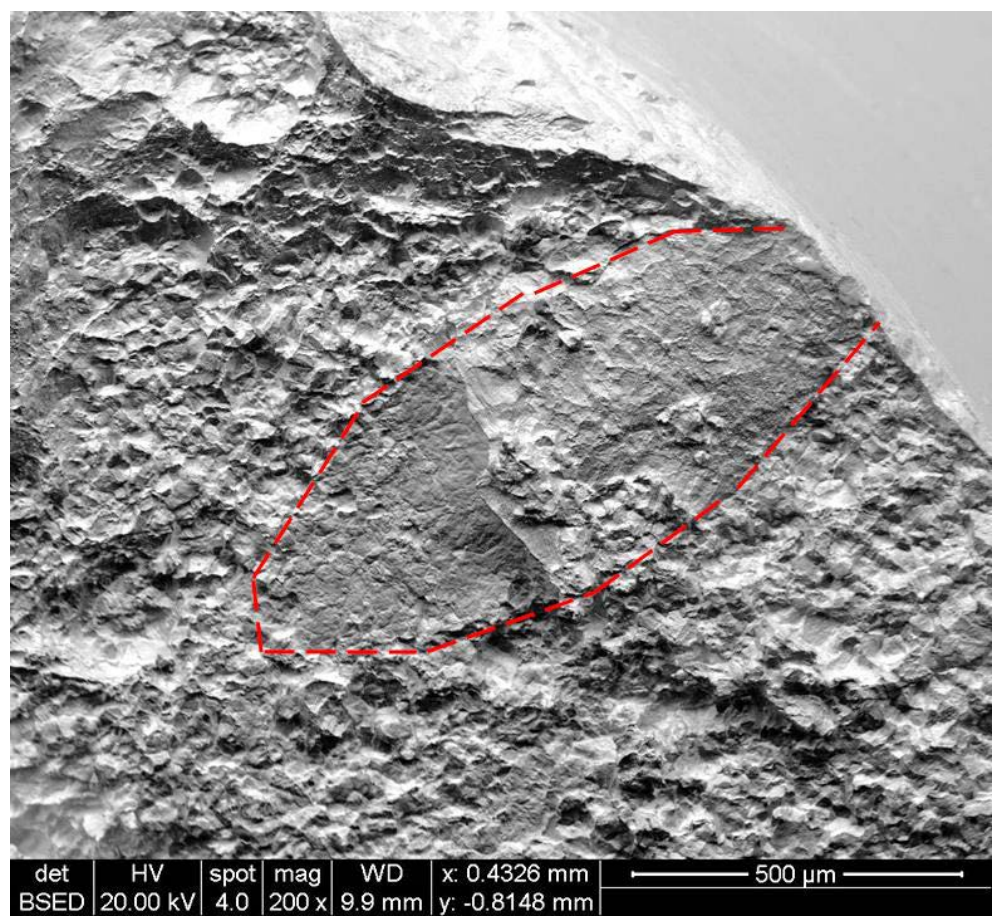

Figure 15: Balloon grain within microstructure of heat 1 orientated into the specimen gauge.
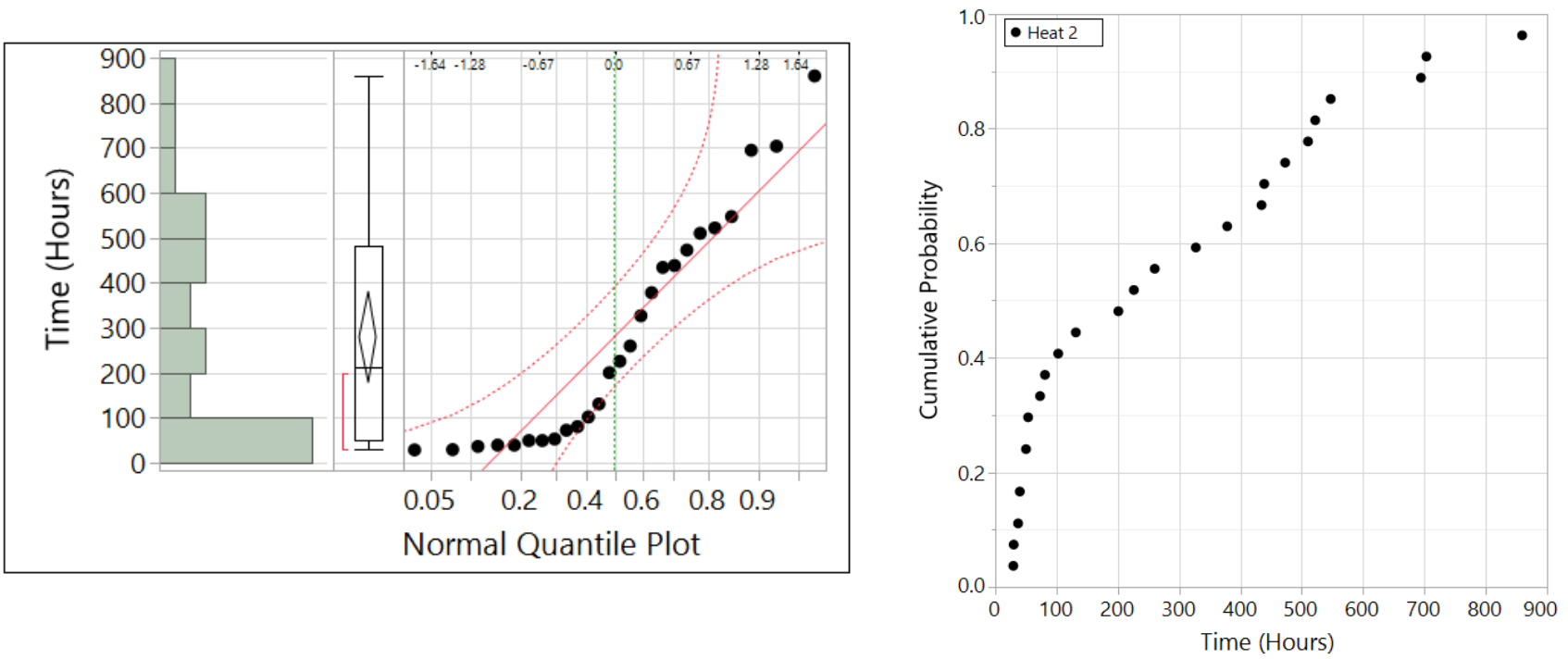

Figure 16: Data frequency and distributions of initiation times for heat 2. 


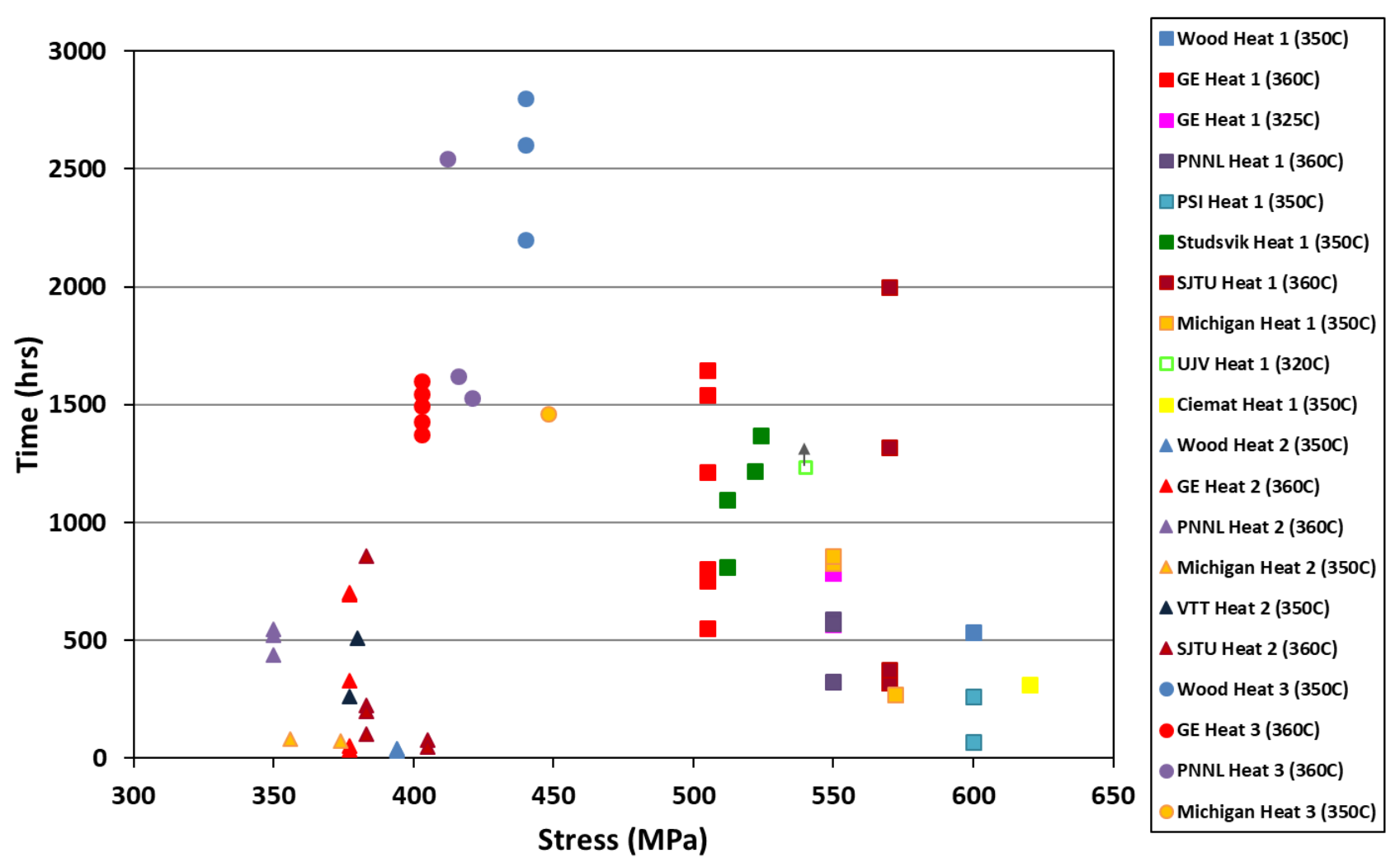

Figure 15: Initiation time vs stress for all specimens tested (corrected to $350^{\circ} \mathrm{C}, 130 \mathrm{~kJ} / \mathrm{mol}$ ). Heat $1(\square)$, heat $2(\Delta)$ and heat $3(\bullet)$. 


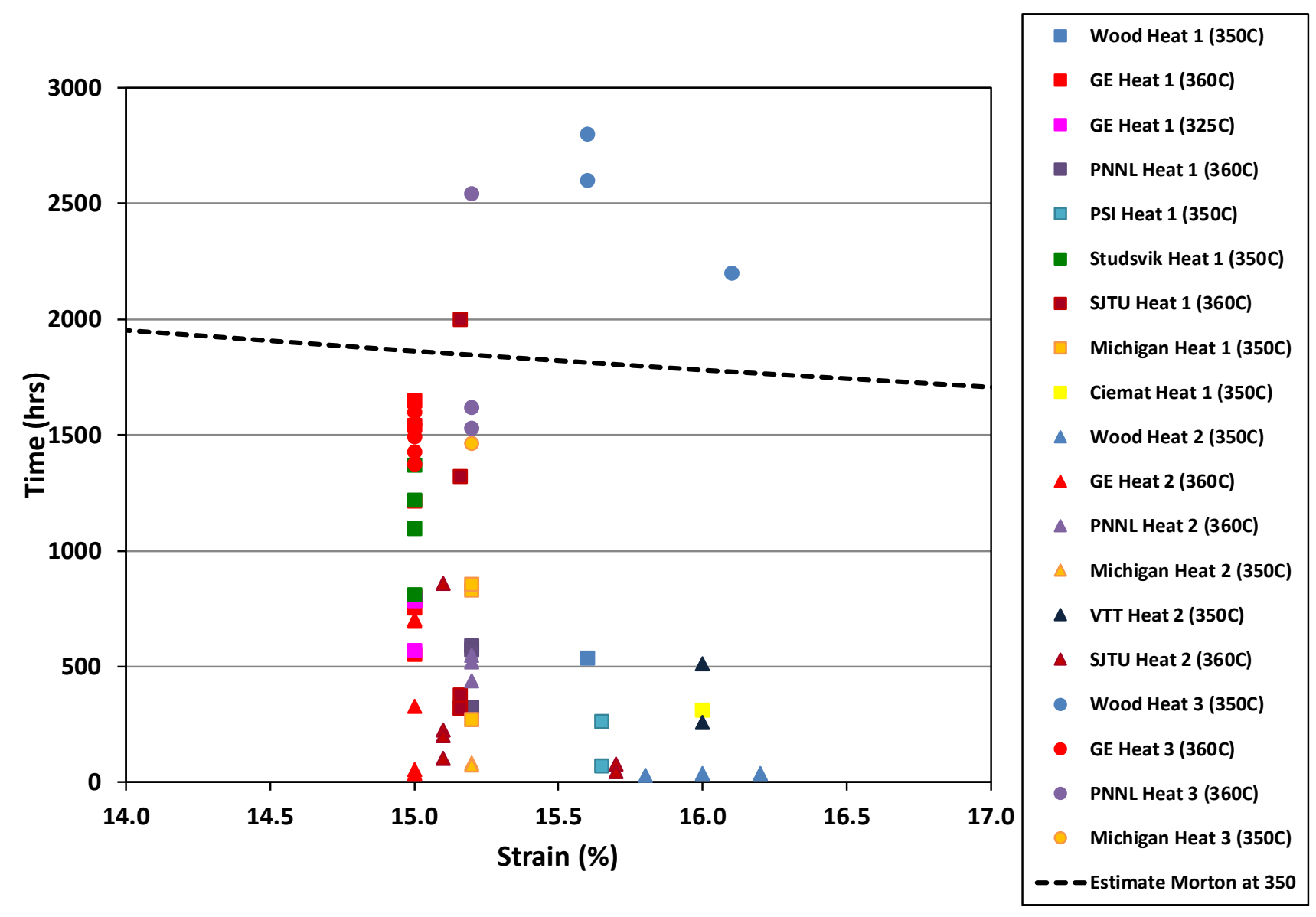

Figure 16: Initiation times vs total strain (prior cold work + in-test strain) (corrected to $\left.350^{\circ} \mathrm{C}, 130 \mathrm{~kJ} / \mathrm{mol}\right)$. Heat $1(\square)$, heat $2(\Delta)$ and heat 3 (O). 